\title{
5. THE PETRO-STATE, ITS POSTAGE STAMPS, AND POLITICAL ICONOGRAPHY
}

Having set the political agenda of creating "the finest city in the Middle East and the happiest State," the government of Kuwait had linked its efforts of state formation and nation-building with the urban transformation of Kuwait City. ${ }^{1}$ In this context, the state was not only interested in actual physical outcomes but also in the visual repercussions of these developments. In the process of moving toward a cradle-to-grave welfare petrostate (which became known as the "Kuwaiti model"), an increasing number of sectors of daily life became regulated, institutionalized, and eventually monitored by the state. With the expansion of the bureaucratic body, the creation of new directorates (which later became ministries), and the issuance of new decrees and laws, the state embraced alternative ways of communicating and representing itself. New possibilities of manifesting the state in public and private spheres arose once new means of communication had become available in Kuwait; these included several large printing presses, the radio (1951), and, later, television (1961). ${ }^{2}$ To communicate recently passed decrees and laws in an official manner beyond the dìwāniyya talks, ${ }^{3}$ the government gazette al-Kuwayt al-Yawm (Kuwait Today) was established as a first step in 1954.

The scenario that unfolded on the cover of al-Kuwayt al-Yawm not only incorporated new modes of viewing and depicting Kuwait City (such as the aerial view) that were already circulating at the time, it also foreshadowed the new political iconography of the state that, by the end of the decade, emerged and sought to position Kuwait (City) as a potent petropolis equal to other petro-states. Neither the new flag design (1961) nor the new coat of arms (1956), which later resulted in the new national emblem (1962), were the medium where this iconography was most radically expressed. Foreshadowed on the

\footnotetext{
1 "Preliminary Report on Development of Kuwait State," February 13, 1952, Kuwait State Development Board, file 101.

${ }^{2}$ For an insightful analysis of Kuwait's print culture, see Khaled Al Najdi and Rosalie Smith McCrea, "The History of Advertising Design in Kuwait: Post-Oil Cultural Shifts 1947-1959," Journal of Design History 25, no. 1 (2012).

${ }^{3}$ For an in-depth analysis of the role of the social gathering spaces known as dìwāniyyāt in Kuwaiti sociopolitical life, see James C. A. Redman, “The Diwaniyya: Guestroom Sociability and Bureaucratic Brokerage in Kuwait” (PhD diss., University of Utah, 2014), accessed January 31, 2021, https://core.ac.uk/download/ pdf/276264928.pdf.
} 
gazette's cover, the new iconography of Kuwait the oil state unfolded fully in the first series of Kuwaiti postage stamps (1959).

This first set of internationally valid stamps was not just aesthetically and iconographically impactful, it also created substantial political momentum, because the negotiation over the postal takeover from the British marked a decisive step toward political independence. In the following, the Kuwaiti government secured full control over postal communication with all nations and over its visual representation in the form of postage stamps. Stamps are not the most important political symbols per se; rather, their political character depends on the choice of motifs and on the historical context of their issue and reception. In the case of Kuwait, the 1959 series was certainly politically charged.

The main motifs of the stamps were the portrait of Shaykh Abdullah, wooden sailing boats, several newly built architectural structures (such as a desalination plant), and oil infrastructure (such as derricks). While the Kuwait Oil Company (KOC) strove to photographically integrate Kuwait City into its corporate sphere, the government of Kuwait - who already "owned" the city-visually claimed the oil infrastructure in order to position Kuwait as a petro-state. Both the KOC and the government relied on colorful "images of urban space and urban life ... to construct a visual argument about oil as a national resource." ${ }^{4}$ In both cases, the translation of the modern built environment into widely circulating images worked "as evidence that these nation-states were plugged into the modern world" and were actively participating in petro-modernity. ${ }^{5}$ But the KOC and the government employed their visual narratives to different ends.

The oil company used (color) photography to highlight the benefits of petroleum for the host country and for society in general by staging Kuwait City as vibrant metropolis due to oil (industrialization), thereby legitimizing its operations. The government was concerned with gaining international visibility as a confident, modernizing, and prosperous nation-state. To achieve this, it visually claimed the oil infrastructure and, thus, the oil production taking place on Kuwaiti territory in postage stamp motifs as a symbolic gesture of "nationalization." This occurred irrespective of the fact that the government was not in charge of production, not the owner of the oil industry, and that it received only 50 percent of the revenues generated by oil extraction. In the mid-twentieth century, issuing postage stamps with oil motifs became one of the key visual strategies of oil-producing and oil-refining countries to (inter)nationally showcase their relationship with petroleum in an assertive way. When presenting the new set in 1959, Kuwait embraced this visual tactic more than any other Arab petro-state. Leading up to this bold move, designing the government gazette was a decisive step.

\footnotetext{
${ }^{4}$ Damluji, “Petroleum's Promise," 135.

${ }^{5}$ Ibid., 9.
} 


\subsection{Kuwait's Image-World on the Cover of the Government Gazette}

On December 11, 1954, the Kuwaiti government initiated al-Kuwayt al-Yawm (Kuwait Today) as its official weekly newspaper (jarīda rasmìyya usbū'ìya). With its characteristic bright blue cover design (which has remained almost unchanged), the gazette makes a strong visual appearance to this day (fig. 5.1). ${ }^{6}$

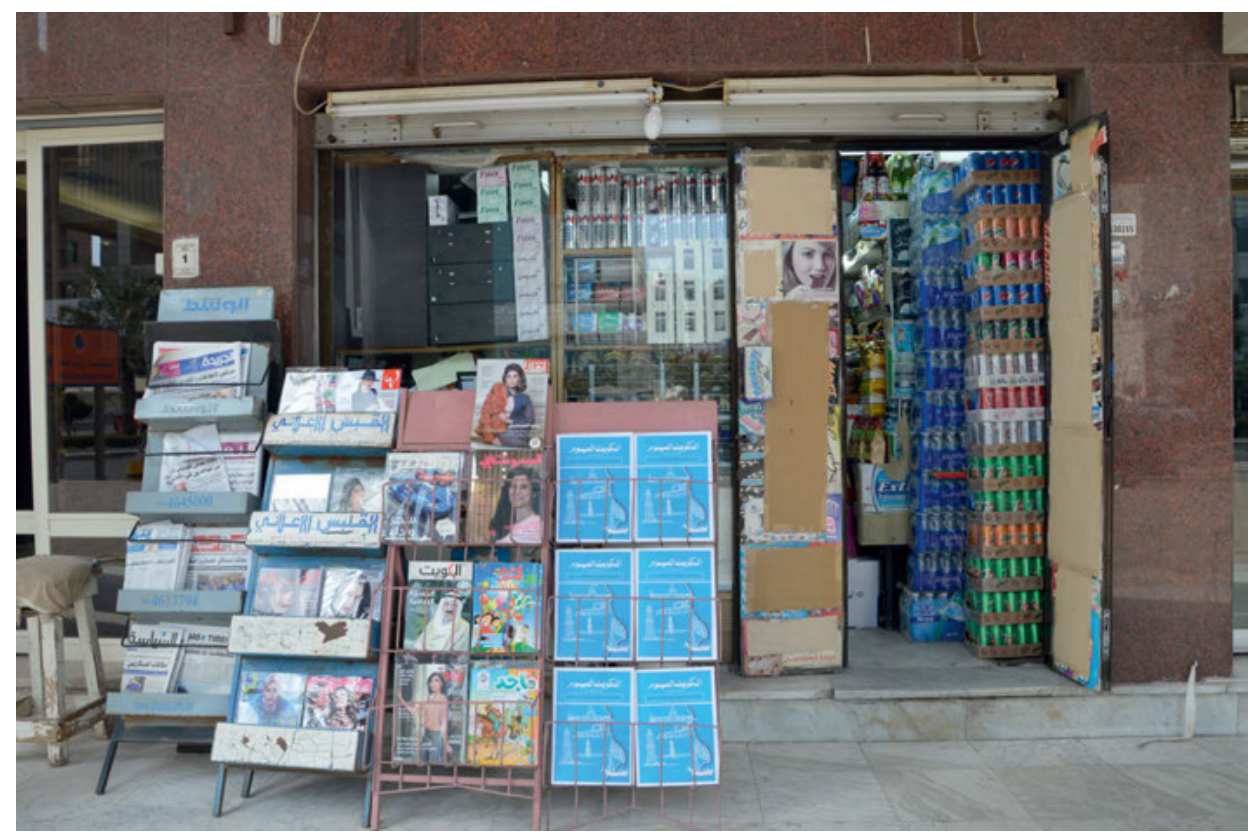

5.1 Display stand with issues of al-Kuwayt al-Yawm outside a biqāla (kiosk) in Sharq, Kuwait City.

The cover of Kuwait Today is divided into two sections (fig. 5.2). In the upper section, the title and subtitle are displayed. The lower, larger section consists of several white line drawings. From top to bottom, we find Shuwaikh Secondary School's main building as seen from the seaside (fig. 5.3); ${ }^{7}$ an industrial complex consisting of three warehouses and smoking chimneys; two oil derricks viewed from different distances; and a sailing boat in

\footnotetext{
${ }^{6}$ See Al Najdi and Smith McCrea, "The History of Advertising Design in Kuwait," 58-60. Recent issues of the gazette no longer display the Kuwaiti coat of arms and the subtitle, but show the issue number and year instead.

7 Shuwaikh Secondary School was first opened in 1953, although construction continued until 1957. In 1966, it became the country's first university. See Fabbri, Saragoça and Camacho, Modern Architecture Kuwait, $40-41$.
} 

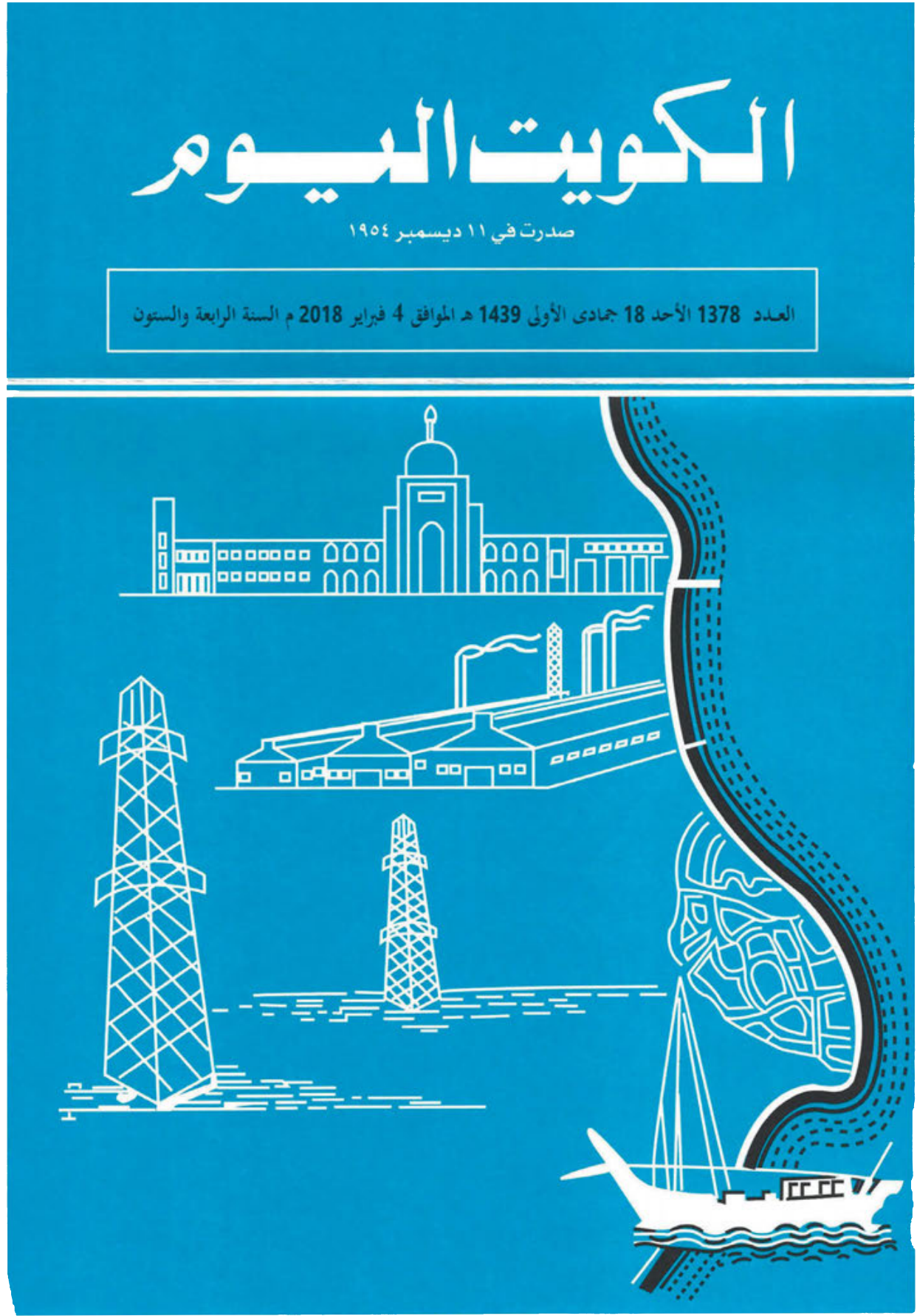

5.2 The cover of the government gazette al-Kuwayt al-Yawm, issue of February 4, 2018. 


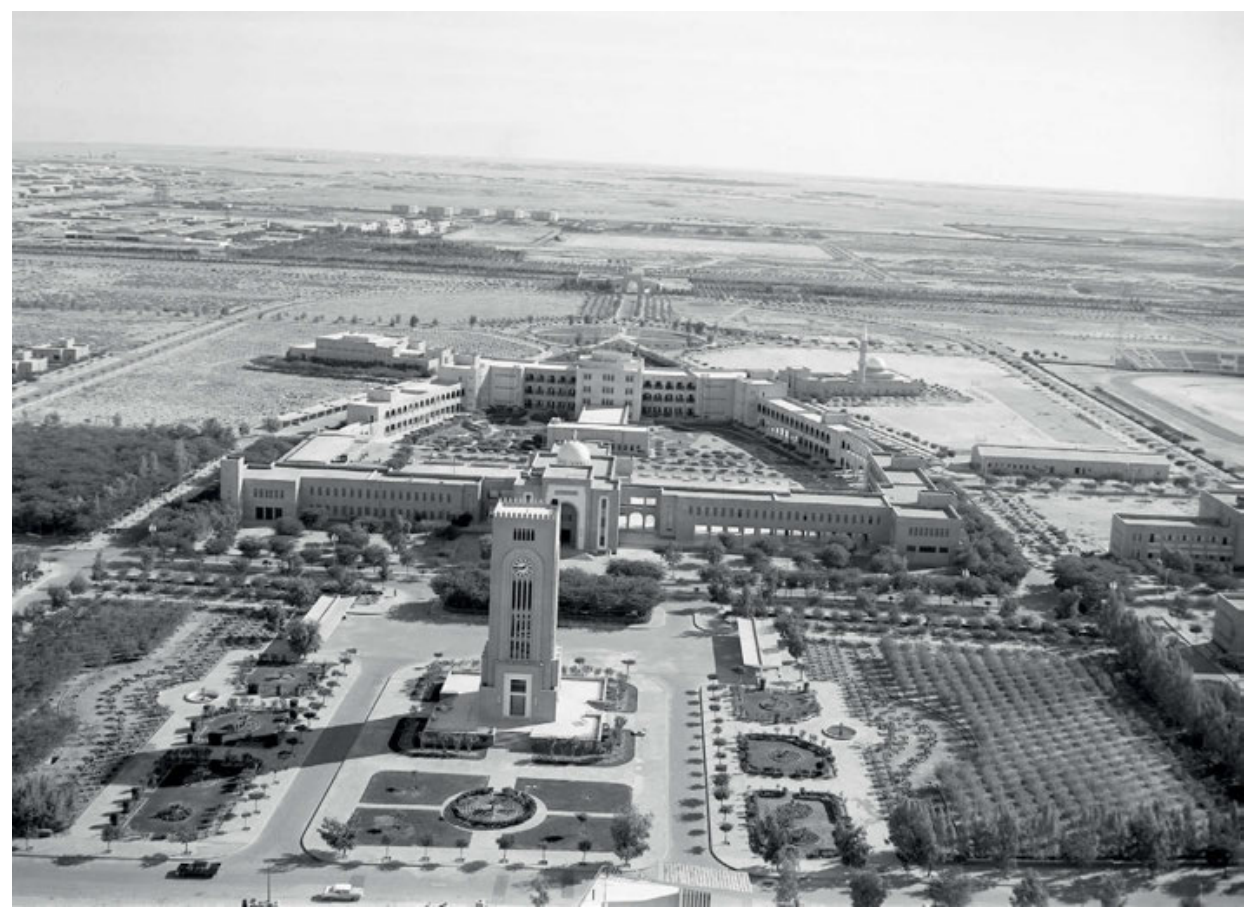

5.3 Oblique view of Shuwaikh Secondary School as seen from the sea. Undated (ca. early 1960s), photographer unknown.

the lower right corner. ${ }^{8}$ This second section of the cover is divided into a land part and a seaside part by a curvy black-and-white line running downward to the bottom of the image. The curvy line represents the characteristically wave-shaped coastline along the spit of Kuwait Bay rotated by 90 degrees. The line divides this section into a seaside (left), where all buildings are situated, and an area afloat (right), the sea, where the dhow moors at the shore. Overall, the cover has remained the same over the decades, except for the Kuwaiti coat of arms that used to be integrated in the upper section (fig. 5.4). The coat of arms was in use between the 1940s and 1956 as both the official state symbol of Kuwait and the official coat of arms of the House of Sabah. ${ }^{9}$

${ }^{8}$ Khaled Al Najdi and Rosalie Smith McCrea claim that the building is a "simple illustration of the Al Seef [Seif] Palace”; Al Najdi and Smith McCrea, “The History of Advertising Design in Kuwait," 63. At the time, however, Seif Palace was not a symmetrical building. The drawing instead depicts Shuwaikh Secondary School, recognizable by its distinctive clock tower with a tapered cupola (see fig. 5.3).

9 To the best of my knowledge, the government stopped issuing al-Kuwayt al-Yawm during the Iraqi invasion. Once publication was resumed, the cover no longer included the subtitle and the coat of arms, but the design has otherwise remained the same. 


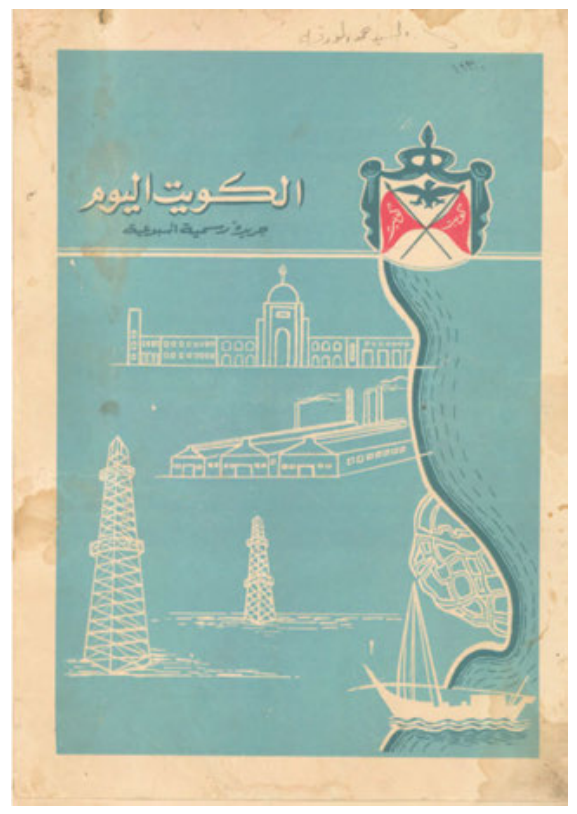

5.4 Historical cover of al-Kuwayt al-Yawm.

The cover clearly integrates the aerial view of the pre-oil town of Kuwait from the 1951 photomosaic and 1952 Master Plan: the black-and-white line alludes to the characteristic shape of the coastline and also references the way in which the "black" sea and the "light-gray" land appeared in the composite aerial photograph. Furthermore, the iconic form of the almond-shaped core of the pre-oil town nesting in the waveshaped spit of Kuwait Bay is also included. However, Kuwait's road network shown here no longer follows the old alleyways; instead, it reflects the new road map proposed in the 1952 Master Plan. The cover of the gazette reproduces the iconic way of seeing and depicting Kuwait from above.

In addition, the design integrates elements that were not yet visible in the aerial survey or even the master plan. Apart from the new road network, two recent additions to the Kuwaiti (visionary) landscape were the secondary school and the industrial complex. Both of these were built in the neighborhood of Shuwaikh, which emerged on the basis of the master plan. The cover even maps these two elements with protruding bar-like piers at their approximate location along the coastline. According to this spatial location, the factory-like building could therefore be part of the developing industrial harbor or the power and desalination plant that opened in March 1953. In contrast to the accurate locations of the buildings, the oil derricks stand in a fictive proximity to the city instead of being located much further south, around the area of Ahmadi and the Burgan Oil Field. The fact that the oil derricks were the only elements not located realistically in this image foreshadows the way in which the government subsequently strove to include images of oil 
infrastructure within their (visual) sphere of influence irrespective of its actual affiliation, most notably in the 1959 set of postage stamps, even if this, at times, meant sacrificing the realism of such renditions.

Differently from the superimposed perpendicular aerial view, which organizes the lower section of the cover as a whole, the line drawings depict the built structures either frontally (the school) or as elevations (the factory, oil derricks) - in line with the fact that no updated photographic vertical view existed of them in 1954. Combining these different modes of viewing is highly innovative and might point to distinct photographic templates for each drawing. As a result, the cover appears like an "on-the-ground" (or, in Haraway's words, "situated") graphic update to the two seminal aerial views of Kuwait, the 1951 photomosaic and the 1952 Master Plan. The cover image both affirms the power of the aerial view as a representation of progress and petro-modernity in the early 1950s and exceeds the initial aerial survey images by updating them.

Under the headline of "Kuwait Today," these different viewpoints and elements merge to visualize Kuwait at the time of the gazette's establishment in 1954. The resulting upto-date portrayal accords with the gazette's agenda to communicate the latest decrees and state news in its role as the official news platform of all departments and national committees. The image collage of Kuwait Today thematically referenced some of the most pressing issues of the time: education, industrialization, the oil industry, and the urban transformation of Kuwait City. The government's activity in these fields was expressed through recently built architecture and (oil) infrastructure as symbolic-pictorial evidence.

Subsequently, the case of producing Kuwaiti postage stamps gained political momentum because the Kuwaiti-British negotiation over the creation of original Kuwaiti stamps and over the postal handover became a catalyst for discussing Kuwaiti independence. This resulted from the fact that the new postage stamps broke with the long line of stamps previously used in Kuwait, which had been overprinted British and British-Indian stamps.

\subsection{Decolonizing Postal Communication}

On February 1, 1959, simultaneously with the issue of the new set of Kuwaiti stamps, the newly established Kuwaiti Administration of Posts, Telegraphs \& Telephones took over the country's internal and external postal services from Britain after long and tedious negotiations. ${ }^{10}$ This postal takeover had several important political implications.

One immediate and tangible outcome was that overprinted British stamps no longer represented Kuwait. Until 1959, overprinted British and British-Indian stamps had been

\footnotetext{
${ }^{10}$ If not stated otherwise, the information in this section is based on the following archival material: Transfer of Responsibility for Postal Services, Part 1, 1953-1959, Post 122/409, British Postal Agency Kuwait, The Royal Mail Archive, London; Transfer of Responsibility for Postal Services, Part 2, 1957-1959, Post 122/410, British Postal Agency Kuwait, The Royal Mail Archive, London.
} 


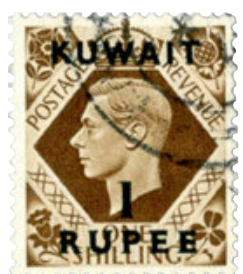

5.5 George VI definitive series, overprinted "KUWAIT" and "RUPEE," issued in 1937.

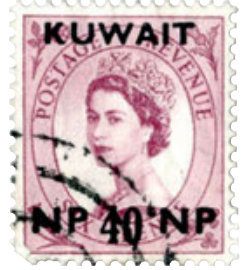

used in Kuwait, indicating the respective political jurisdiction Kuwait was subjected to as a quasi-protectorate of Britain. Issued until India's independence in 1947 by the British Government of India and subsequently by the General Post Office (GPO) in London, these regular stamp sheets, for instance the George VI series and Queen Elisabeth II series, were overprinted with the word "KUWAIT" and, partly, with a different denomination and value, placing the letters and numbers carefully so as not to interfere with the monarch's head (figs. $5.5,5.6)$. With the original Kuwaiti set of 1959, the word "KUWAIT" finally became an integral part of the stamp design, and it was no longer the sovereign of Britain but of Kuwait whose portrait vouched for the validity of the stamp.

Secondly, the postal takeover initiated Kuwait's independence because the handover in effect dissolved the British-Kuwaiti Agreement of 1899 that had made Kuwait a quasi-protectorate of Britain. The treaty had resulted in the additional 1904 Post Office Agreement with Britain, which had defined a British postal monopoly in Kuwait from that point onward. ${ }^{11}$ Now, in order to run the postal services, the Kuwaiti government was obliged to apply for membership with the Universal Postal Union (UPU) as either a sovereign state or a British protectorate-legally, Kuwait was neither of them-so that negotiating the political status of Kuwait became a pressing matter. ${ }^{12}$ Eventually, the debates surrounding the postal takeover and Kuwait's status eventually entered into a larger debate regarding British decolonization in the Gulf and Kuwait's independence in particular. However, on the Kuwaiti side, the initial incentive for discussing a postal takeover had not been anti-imperialist or national interests per se, but rather a dispute over the censorship of Israeli mail in Kuwait in 1956.

Following an appeal by the Arab League to cease mail communication with Israel in the context of the Suez Crisis, around mid-1956, Shaykh Abdullah demanded the boycott of mail to and from Israel through the British-controlled postal services in his country. The British found themselves in a dilemma: not acquiescing to the Shaykh's demand

${ }^{11}$ The Post Office Agreement, signed February 28, 1904, by Shaykh Mubarak, reads as follows: "As the British Government has agreed in accordance with my desire and for the benefit of traders to establish a post office at Koweit [sic], I on my part agree not to allow the establishment here of a post office by any other Government. I accordingly write this undertaking on behalf of myself and my successors." Reprinted in Visit [to the Gulf] by Brigadier K. S. Holmes and Mr. T. U. Meyer, January 1957, 1956-1958, Post 122/3304, British Postal Agencies, Persian Gulf Agency, The Royal Mail Archive, London.

${ }_{12}$ The Universal Postal Union (UPU) was founded by twenty-two states, among them Egypt and the Ottoman Empire, in 1874 in Bern, Switzerland. 
would endanger their position in Kuwait, but acquiescing would strain British-Israeli relations. Eventually, it was suggested that Kuwait should take over the internal postal services, thereby transferring the responsibility (and the blame) for suspending postal services between Israel and Kuwait to the Kuwaiti government itself. By transferring the postal services only partly (internal postal services were to be managed by Kuwait, the external remained with Britain), the British would continue to run and control the delivery of mail between Britain and Kuwait but would not be held responsible for any local delivery stop or censorship of mail. ${ }^{13}$ Rejecting the half-baked proposal, the Kuwaiti representatives successfully pressed for a complete transfer over the period of one year. The Foreign Office consented, presumably wary of adding more fuel to the fire of nationalist, Pan-Arabist but especially anti-British sentiment stirred up by the ongoing Suez Crisis that the Kuwait Oil Company also had problems fighting. In London, the Suez debacle triggered "the first serious re-assessment of the British presence in the Gulf" and, eventually, British withdrawal from the Gulf in the following decades. ${ }^{14}$ However, losing access to oil in Kuwait, Britain's single largest supplier at the time, was not an option. The best way to safeguard economic and political stability in Kuwait, British officials argued, was therefore to foster Kuwait's independence from other countries' influence. This also implied a disconnection from Britain, as Kuwait's status as a semi-protectorate was "widely regarded as 'imperialistic and anachronistic."” 15

While negotiating the terms of the transfer, the British tried to secure their interests; these were listed as: "(a) the maintenance of an efficient postal service and of British advice; (b) that the Egyptians do not take over; and (c) Kuwaiti goodwill." ${ }^{16}$ Above all, sustaining well-running postal services meant safeguarding communication between the British representatives and companies active in Kuwait and Britain, among them the Kuwait Oil Company and many construction companies. Considering the Suez Crisis, the British were anxious to keep Kuwait out of the Egyptian sphere of (anti-British) influence and to deliver the best postal service possible. The postal services had become an important political issue not only in order to maintain influence, but also to secure Britain's reputation by ensuring that, at the time of the handover, "the Kuwaitis will not be able to improve upon the service

\footnotetext{
${ }_{13}$ Memorandum on Kuwait Postal Censorship, June 1956, Transfer of Responsibility for Postal Services, Part 1.

${ }^{14}$ Simon C. Smith, "Britain's Decision to Withdraw from the Persian Gulf: A Pattern Not a Puzzle," The Journal of Imperial and Commonwealth History 44, no. 2 (2016): 330. On the decolonization of British-held territories in the Middle East and especially the Persian Gulf, see also David George Boyce, Decolonisation and the British Empire, 1775-1997 (Basingstoke: Macmillan, 1999), 150-76; John Darwin, Britain and Decolonisation: The Retreat from Empire in the Post-War World (Basingstoke: Macmillan, 1988).

${ }^{15}$ Smith, "Britain's Decision to Withdraw from the Persian Gulf," 331-32.

${ }^{16}$ Foreign Office to Political Agency Kuwait, telegram, January 10, 1957, Transfer of Responsibility for Postal Services, Part 1
} 
previously provided by the British Post Office." ${ }^{17}$ To this end, hoping to prolong the process and to improve British postal performance in the meantime, the British subjected Kuwait's postal takeover to a set of conditions. These conditions were: new Kuwaiti stamps had to be ready in time, their design and printing had to be organized and paid for by Kuwait; Kuwaiti personnel had to be trained in Britain for at least one year; and an adequate building had to be provided to set up a new post office.

Between 1957 and 1959, Kuwaiti personnel were trained in Britain, Kuwaiti stamps were developed, and several new post offices were opened across town, among them the new General Post Office in Fahad al-Salem Street. On February 1, 1959, Khalid Abdullatif Al-Abdul Razzak, Director General of the Administration of Posts, Telegraphs \& Telephones, officially inaugurated the General Post Office and introduced the 1959 set of stamps. In his speech, he pointed to the successful accomplishment of architectural facilities (post offices) and the design of the equipment necessary to perform postal services (stamps, cancellations) and concluded that "we have done our best to provide our dear State with the dignity and honour it deserves among our sister Arab States and the other States." ${ }^{18}$ Razzak continued by saying that that particular day, which also coincided with the first anniversary of the United Arab Republic, marked "the start of a new regime for our existence and for the liberty of our Dear state." ${ }^{19}$ Demonstrating Kuwait's successful takeover of the postal services was crucial to Kuwait's decolonization, to becoming a modern nation-state, and to performing as one. Postage stamps as political symbols were vital for claiming a position of being equal among others ("our sister Arab States and the other States") and for establishing a distinct (and independent) national identity ("new regime") that was to be visually communicated. ${ }^{20}$

\subsection{The First Set of Kuwaiti Postage Pictures}

The 1959 set of Kuwaiti postage stamps was a milestone (fig. 5.7). ${ }^{21}$ It was the first set of stamps depicting motifs from Kuwait that was issued by Kuwaiti authorities and that was valid for local and international use. The stamps functioned as Kuwaiti political symbols despite the fact that the thirteen-piece set was designed and printed by the renowned

\footnotetext{
${ }_{17}$ Miss King, General Post Office London, to D. J. M. Lashmar, British Postal Agencies Bahrain, July 20, 1956, Post Office Accommodation, Part 3, 1953-1956, Post 122/1063, British Postal Agency Kuwait, The Royal Mail Archive, London.

${ }_{18}$ Khalid Abdullatif Al-Abdul Razzak's opening speech, February 1, 1959, English translation provided by British post officials, Transfer of Responsibility for Postal Services, Part 2.

${ }_{19}$ Ibid. The UAR's anniversary resulted in pro-Nasserist mobilization in Kuwait and many other places; see John T. Chalcraft, Popular Politics in the Making of the Modern Middle East (Cambridge, UK: Cambridge University Press, 2016), 345.

${ }^{20}$ See Anderson, Imagined Communities, 81.

${ }^{21}$ A first analysis of the Kuwaiti set and oil stamps from the MENA region was published in: Hindelang, "Oil Media: Changing Portraits of Petroleum in Visual Culture Between the US, Kuwait, and Switzerland."
} 


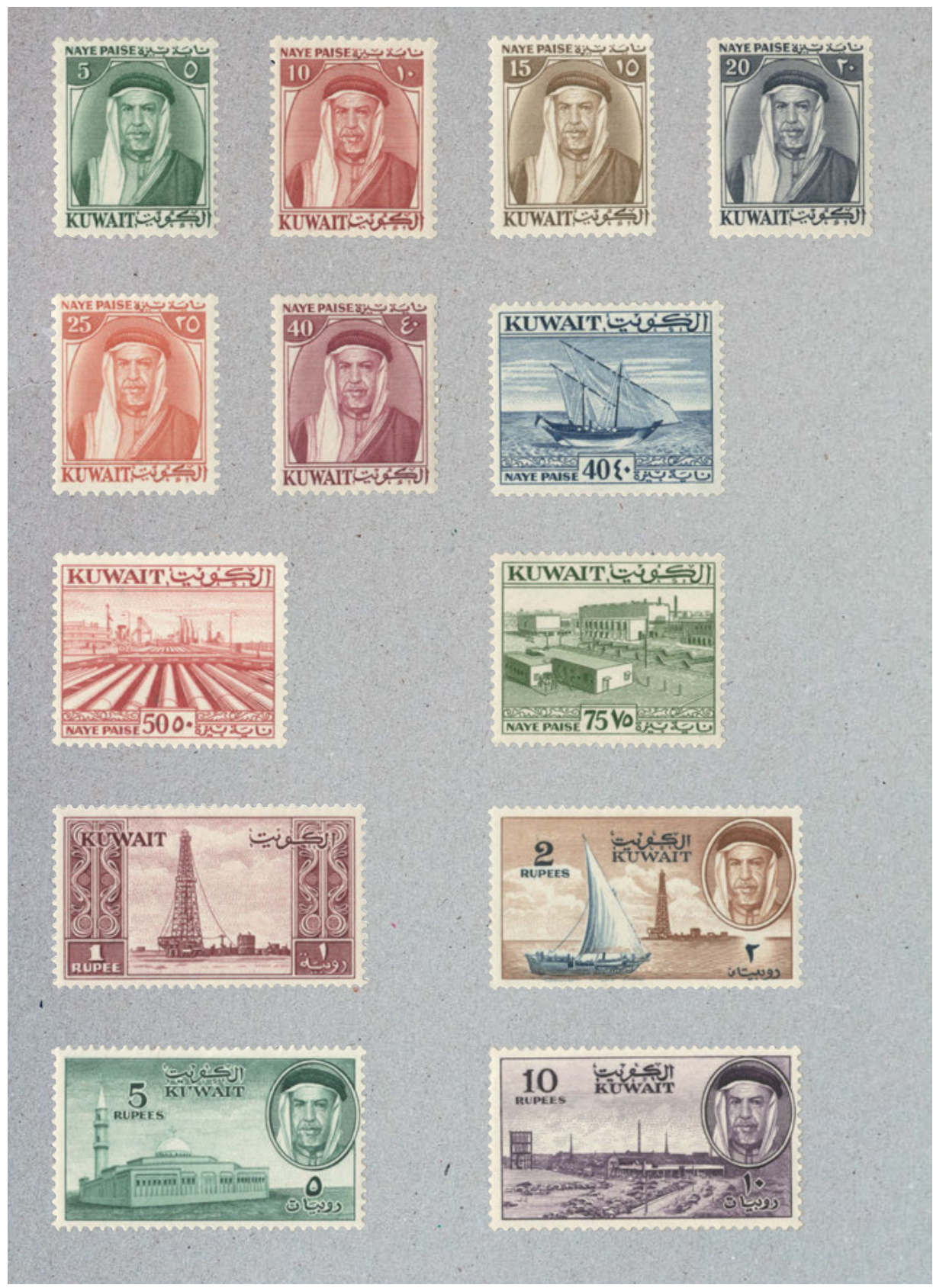

5.7 The 1959 series of Kuwaiti definitives. Shaykh Abdullah (5 to 40 naye paise); two-masted dhow (40 np); the oil harbor Mina al-Ahmadi (50 np); power and desalination plant (75 np); oil rig (1 rupee); dhow and oil rig (2 rupees); mosque of Shuwaikh Secondary School (5 rupees); Safat Square (10 rupees). 
British stamp company Thomas De La Rue in London, a company that British officials had promoted in order to secure the commission for a British firm in a similar way to the commission of British urban planners for Kuwait's first master plan. ${ }^{22}$ Given the difficulty that details and documents about the design process are extremely scarce and the names of designers and etchers are unknown, the final stamp designs are the most important material for an analysis of Kuwait's new political iconography. ${ }^{23}$ These richly detailed postage pictures invite an analysis that considers them not merely from a semiotic point of view (as most research on stamps usually does) but regards them as aesthetic-symbolic objects.

\section{Stamps as Aesthetic-Symbolic Objects}

Since the nineteenth century and the issue of the very first stamp, the British Penny Black (1840), postage stamps have followed a more or less internationally standardized format. Perforated on all sides, the stamp's face usually displays the name of the issuing country and its value, making it a receipt of what the sender paid for transport to the issuing body. In the past, the reverse was usually gummed using dextrin, gum arabic, or, since roughly the 1960s, synthetic gums like polyvinyl alcohol (a petroleum derivative); today, most stamps are self-adhesive. ${ }^{24}$ Stamps are of rectangular format and of very small size; they often use special typography, which in the case of a non-Roman script like Arabic is often accompanied by the same word(s) in Roman letters. Stamp designs can include ornamentation or graphics in combination with abstract, numerical, or pictorial images. They are, in effect, "miniature prints with a very high circulation." ${ }^{25}$

Philatelists classify stamps dominated by a picture other than a portrait, heraldic element, or number as pictorial stamps. ${ }^{26}$ Due to their elaborate color printing, pictorials

${ }^{22}$ Gawain W. Bell, Political Agent, to D. M. H. Riches, Foreign Office, March 7, 1957, Transfer of Responsibility for Postal Services, Part 1. Thomas De La Rue, one of the oldest banknote manufacturers and stamp printing companies, started printing stamps for the United Kingdom as early as 1855 . Quickly, stamp commissions for British colonies and protectorates as well as for Italy and the Confederate States of America followed. Having developed a new surface printing technique, the company continued to hold a market-leading position in the second half of the twentieth century. For a detailed history of the company see Frank Walton, The De La Rue Collection, 6 vols. (London: The Royal Philatelic Society London, 2014).

${ }^{23}$ Unfortunately, Thomas De La Rue dissolved and sold the company archives in the 1970s. Email by Paul Skinner, Lead Curator of the Philatelic Collections, British Library, to the author, October 6, 2017. Except for Ramzi Kayello, who designed an oil commemoration stamp in 1966, no artist involved in stamp designs for Kuwait for the period 1958-1985 has been recorded according to my knowledge.

${ }^{24}$ Jane Ormrod, "Response to 'What Is the Glue on the Back of Postage Stamps and Envelopes Made From?'” The Guardian, 2011, accessed January 31, 2021, https://www.theguardian.com/notesandqueries/ query/0,-1680,00.html.

${ }^{25}$ Gottfried Gabriel, “Ästhetik und Politische Ikonographie der Briefmarke," Zeitschrift für Ästhetik und Allgemeine Kunstwissenschaft 54, no.2 (2009): 190 (author's translation).

${ }^{26}$ Philately is the practice of collecting, systematically organizing, and studying postage stamps and other related material like stationery and cancellations. 
are costly and therefore often issued as commemorative or special issues rather than as regular series, which are called definitives. Yet, the 1959 Kuwaiti issue was a set of pictorial definitives with eight individual designs that were extremely well executed and detailed due to the costly and sophisticated technique of etching used here. Even devoid of archival information about the design process, it is clear that the set was made with great professional care in order to deliver an excellent result according to stamp printing standards of the time.

Despite their obvious aesthetic qualities, postage stamps are hardly ever analyzed as aesthetic-symbolic objects. Almost all stamp studies that were recently published within various disciplines and fields focus on topics such as semiotics, political representation and propaganda, identity construction, and iconography. ${ }^{27}$ The few scholars that have discussed the stamps of modern Arab countries mirror these thematic emphases. ${ }^{28}$ Virtually no studies apply a formal or stylistic image analysis, and art-historical approaches in general are mostly absent. ${ }^{29}$ This is especially surprising given that, in the first half of the twentieth century, influential intellectuals of art history and cultural studies like Aby Warburg, Nikolaus Pevsner, and Walter Benjamin recognized stamps as aesthetic objects with political-iconographical and historical relevance, and appreciated them as such. ${ }^{30}$ Their writings have recently received renewed attention.

\footnotetext{
${ }^{27}$ Recent studies that also provide valuable general reflections on stamps include: Pierre Smolarski, René Smolarski, and Silke Vetter-Schultheiss, eds., Gezähnte Geschichte: Die Briefmarke als historische Quelle, Post-Wert-Zeichen 1 (Göttingen: V\&R Unipress, 2019); Stanley D. Brunn, "Stamps as Messengers of Political Transition," Geographical Review 101, no. 1 (2011); Daniel Hammett, "Envisaging the Nation: The Philatelic Iconography of Transforming South African National Narratives," Geopolitics 17, no. 3 (2012); Alexander Hanisch-Wolfram, Postalische Identitätskonstruktionen: Briefmarken als Medien totalitärer Propaganda, Kommunikationswissenschaft und Publizistik 95 (Frankfurt: Peter Lang, 2006); Peter Jones, "Posting the Future: British Stamp Design and the 'White Heat' of a Technological Revolution," Journal of Design History 17, no. 2 (2004); Hans-Jürgen Köppel, Politik auf Briefmarken: 130 Jahre Propaganda auf Postwertzeichen (Düsseldorf: Droste, 1971).

${ }^{28}$ See Roswitha Badry, "Posta," in Encyclopaedia of Islam: Second Online Edition, ed. Peri J. Bearman et al. (Leiden: Brill, 2012), accessed April 17, 2020, https://doi.org/10.1163/1573-3912_islam_SIM_6138; Yuka Kadoi, "Postage Stamps in Islamic Art," Grove Art Online, July 2, 2009, accessed January 31, 2021, https:// doi.org/10.1093/gao/9781884446054.article.T2082293; Donald M. Reid, "The Postage Stamp: A Window on Saddam Hussein's Iraq," Middle East Journal 47, no. 1 (1993); Roswitha Badry and Johannes Niehoff, Die ideologische Botschaft von Briefmarken: Dargestellt am Beispiel Libyens und des Iran (Tübingen: Niehoff, 1988); Emmanuel Sivan, “The Arab Nation-State: In Search of a Usable Past," Middle East Review 19, no. 3 (1987); Donald M. Reid, “The Symbolism of Postage Stamps: A Source for the Historian,” Journal of Contemporary History 19, no. 2 (April 1984); Harry W. Hazard, "Islamic Philately as an Ancillary Discipline," in The World of Islam: Studies in Honour of Philip K. Hitti, ed. James Kritzeck and Richard B. Winder, repr. ed. (London: Macmillan, [1959] 1960).

${ }^{29}$ Gottfried Gabriel also notes the scarcity of art historical research on stamps and discusses the few existing ones in detail; see Gabriel, "Ästhetik und Politische Ikonographie der Briefmarke," 186, fn. 19.

${ }^{30}$ Ibid., 184-85; Nikolaus Pevsner, "Style in Stamps: A Century of Postal Design,” Country Life, May 4, 1940, as quoted in Keith Jeffery, "Crown, Communication and the Colonial Post: Stamps, the Monarchy and the
} 
Art historian Frank Zöllner, for example, traces the historical relationship between postage stamps and art historiography by examining the writing, thinking, and stamp collecting activities of Aby Warburg, an ardent philatelist. ${ }^{31}$ Warburg's logic of organizing postage stamps correlates strongly with his concept of "pictorial argumentation" (Bildargumentation) and with the organizational system of his most famous project, the Mnemosyne Atlas. In both cases Warburg focused on classically inspired allegorical, symbolical, and heraldic imagery, state iconography and portraits of rulers-in other words, classical stamp motifs. Warburg described postage stamps as the "pictorial language of world traffic" (Bildersprache des Weltverkehrs), which clearly shows the importance he attributed to their mobilized visual expression. ${ }^{32}$ Apart from Warburg, another prominent philatelist and influential intellectual in this field was none other than Walter Benjamin, who called stamps the "business cards of states," thereby highlighting their self-representative value for communication with other (nation-)states. ${ }^{33}$

Reconnecting with these early efforts of recognizing postage stamps as aestheticsymbolic objects with a political iconography, the following detailed description of the 1959 Kuwaiti set of stamps provides the necessary foundation for analyzing their potential as symbols of a new political aesthetic of Kuwait's petro-modernity and as a pictorial language of communication with other petro-states, and, generally, people.

\section{The 1959 Kuwaiti Stamps and Their Templates}

Each of the thirteen definitives which comprise the 1959 set displays the country name (Kuwait) and the denomination (rupee and naye paise) in Roman (English) and Arabic script (see fig. 5.7); ${ }^{34}$ the value of each stamp is given in (Hindu-)Arabic and Eastern Arabic numerals. Following the respective reading direction, the English is always located

British Empire," The Journal of Imperial and Commonwealth History 34, no. 1 (2006): 46.

${ }^{31}$ Frank Zöllner, "Philatelie, politische Philatelie," Frankfurter Allgemeine Zeitung, June 27, 2012, 4; Frank Zöllner, “Im Geistesverkehr der Welt’: Aby Warburg und die Philatelie,” Das Archiv, no. 3 (2016): 14-21. On Aby Warburg and stamps, see Aby Warburg, "Die Funktion des Briefmarkenbildes im Geistesverkehr der Welt (1927)," in Aby Warburg: Bilderreihen und Ausstellungen, ed. Uwe Fleckner and Isabella Woldt, Aby Warburg Gesammelte Schriften vol.2.2 (Berlin: Akademie Verlag, 2011); Ulrich Raulff, "Der aufhaltsame Aufstieg einer Idee: Warburg und die Vernuft der Republik," in Wilde Energien: Vier Versuche zu Aby Warburg, ed. Ulrich Raulff, Göttinger Gespräche zur Geschichtswissenschaft 19 (Göttingen: Wallstein, 2003).

32 Aby Warburg and Edwin Redslob, “Die Briefmarke als Kulturdokument," essay published in Hamburger Nachrichten, August 15, 1927, and reprinted in Gabriel, "Ästhetik und Politische Ikonographie der Briefmarke," 200-01. Warburg even intended to write a book on the cultural history of the stamp and designed an air mail stamp for Germany in 1926. See Zöllner, "Philatelie, politische Philatelie," 4.

${ }^{33}$ Walter Benjamin, "Briefmarken-Handlungen," in Walter Benjamin: Werke und Nachlaß, Kritische Gesamtausgabe: Einbahnstraße (1928), vol. 8, ed. Detlev Schöttker and Steffen Haug (Frankfurt: Suhrkamp, 2009), 186.

${ }^{34}$ On the use of different Arabic calligraphies for later issues of Kuwaiti postage stamps, see Neil Donaldson, "Arabica Bracadabra," Gibbons Stamp Monthly 1 (January 1970). 

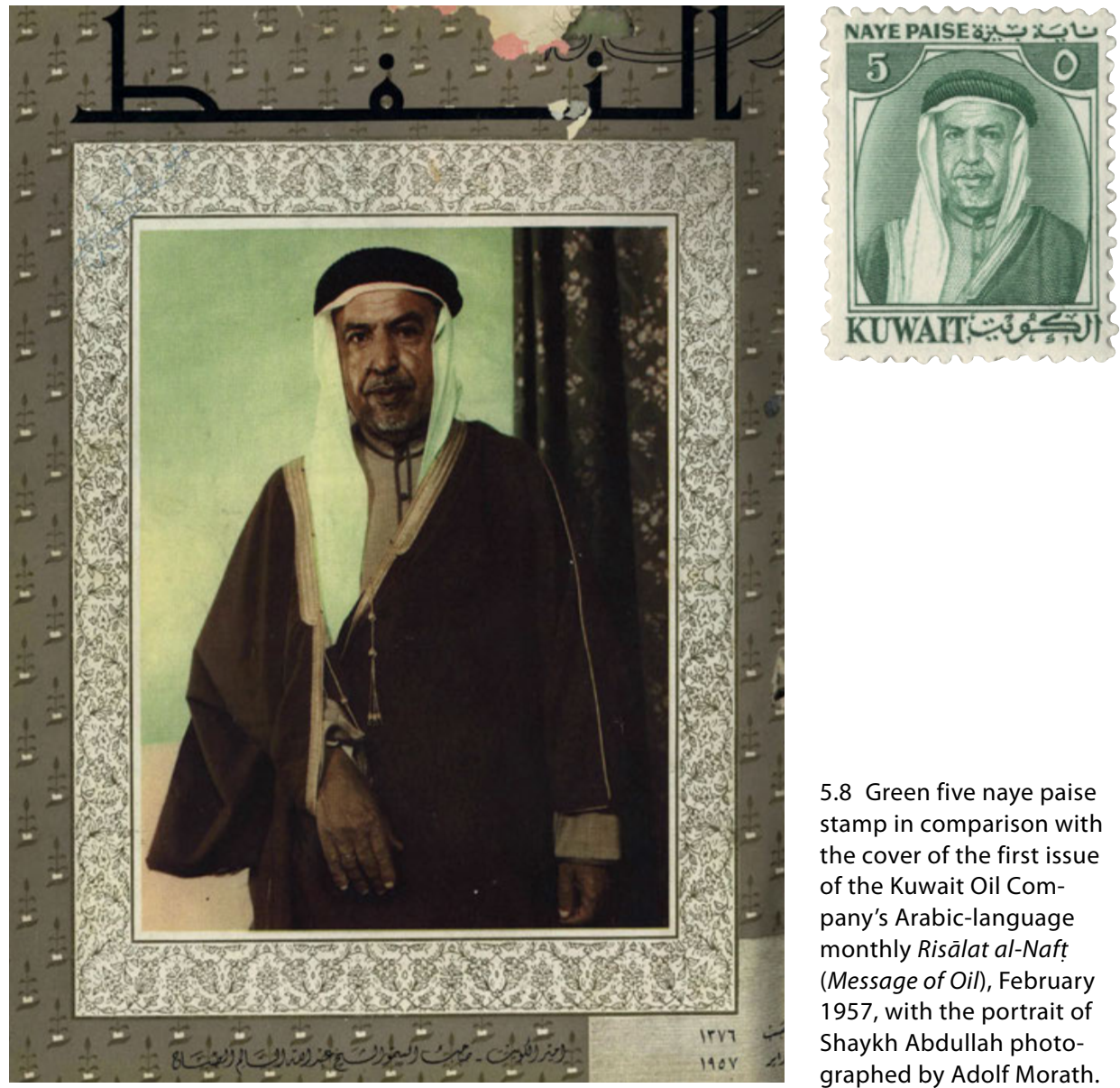

5.8 Green five naye paise stamp in comparison with the cover of the first issue of the Kuwait Oil Company's Arabic-language monthly Risālat al-Naft (Message of Oil), February 1957, with the portrait of Shaykh Abdullah photographed by Adolf Morath.

on the left-hand side and the Arabic on the right-hand side. Before the introduction of the national currency (dinar and fils) in 1960, Kuwait used the Indian rupee and its smaller denomination, the naye paise. ${ }^{35}$ The 1959 Kuwaiti set shows a portrait of Shaykh Abdullah on the six smallest values, while each of the remaining seven stamps have a different motif. ${ }^{36}$ Overall, the set features four compositional schemes: in the first group, the five,

${ }^{35}$ Most of the Persian Gulf used the Indian rupee until, in May 1959, an amended version of the Indian rupee especially for the Persian Gulf region that was equivalent in value to the regular Indian rupee was issued. The new rupee was implemented as part of a strategy to stop illegal trading. See for example Peter Symes, "Gulf Rupees: A History," Reference Site for Islamic Banknotes (website), accessed January 31, 2021, https://web. archive.org/web/20030630072004/http://www.islamicbanknotes.com/gulfrupees\%20(article).htm.

${ }^{36}$ The rose claret forty naye paise portrait stamp was withdrawn two weeks after the set was issued, apparently because its color was too similar to the red ten naye paise stamp and because the set should not contain 
ten, fifteen, twenty, twenty-five, and forty naye paise stamps depict the full-face portrait of Shaykh Abdullah, Kuwait's ruler (fig. 5.8). ${ }^{37}$ The oval-shaped portrait of his head and shoulders shows him wearing the official formal dress in which he was photographed on many occasions, including by Adolf Morath. Most likely it was a portrait of the Shaykh that Morath took for the cover of the KOC's Arabic-language monthly Risālat al-Naft (Message of Oil) that served as template for the stamp, which was first released in February 1957 on the anniversary of the ruler's accession. ${ }^{38}$ This formal dress consists of a dark robe with golden embroidery along the seams and golden piping (bisht dhahabi $)$ above a lighter colored thawb with a banded collar and button facing, and a headdress of light cloth (ghutra) with a dark headrope ('iqāl). ${ }^{39}$ Abdullah's formal appearance is furthermore strengthened by his austere look and the presentation of the image: the oval portrait is overlayered by a rectangular frame, with quarter-circles in the upper corners carrying the denomination in white numbers against a dark background. In a similar way to photographs, the posture and double framing "distinguish relations between photographic space and the viewer's space." 40 The portrait thereby creates a timeless distance from the viewer that seemingly observes the rules of protocol of how to encounter the ruler. Below the image, the writing Kuwait and al-Kuwayt acts as the title of the stamp. It is through this combination of words and image that Shaykh Abdullah came to personify Kuwait on the first official Kuwaiti stamp.

The forty, fifty, and seventy-five naye paise stamps form the second compositional group. Each of them contains a framed image in landscape format. At the top, a bar displays the country name in Arabic and English and the prominent typographies visually link the writing with the illustrations. Below the picture, two smaller bars contain ornamentations (upper bar) and the denomination in words (lower bar). The numerical denomination is stated centrally across both bars.

The dark blue forty naye paise stamp shows a traditional two-masted dhow sailing on the open sea, with thin lines indicating the movement of the waves (fig. 5.9). The ship is depicted as if viewed from another boat beside it. The image of this wooden sailing vessel, a type called $b \bar{u} m$, references the pre-oil economy and maritime lifeworld of Kuwait. Khaled Alabdulmughni, a Kuwaiti philatelist, suggests that the design template for this stamp was a photograph of a miniature boat, a type called sambük, on display in

\footnotetext{
two forty naye paise stamps.

${ }^{37}$ A year earlier, a first set of three stamps with the ruler's portrait that were identical in design to the 1959 ones and also printed by De La Rue had been issued. The 1958 set was valid for local use only and served as a pre-stage to the full set that was issued a year later.

${ }^{38}$ I thank Khaled Alabdulmughni for pointing this out and for providing the historical visual material.

${ }^{39}$ This formal combination was already more "simplified and standardized" in its decoration than outfits still worn a decade earlier, even though the basic elements were the same. Bruce Ingham, "Men's Dress in the Arabian Peninsula: Historical and Present Perspectives," in Languages of Dress in the Middle East, ed. Nancy Lindisfarne-Tapper and Bruce Ingham (Richmond: Curzon, 1997), 50-51.

${ }^{40}$ Edwards, "Material Beings," 68.
} 

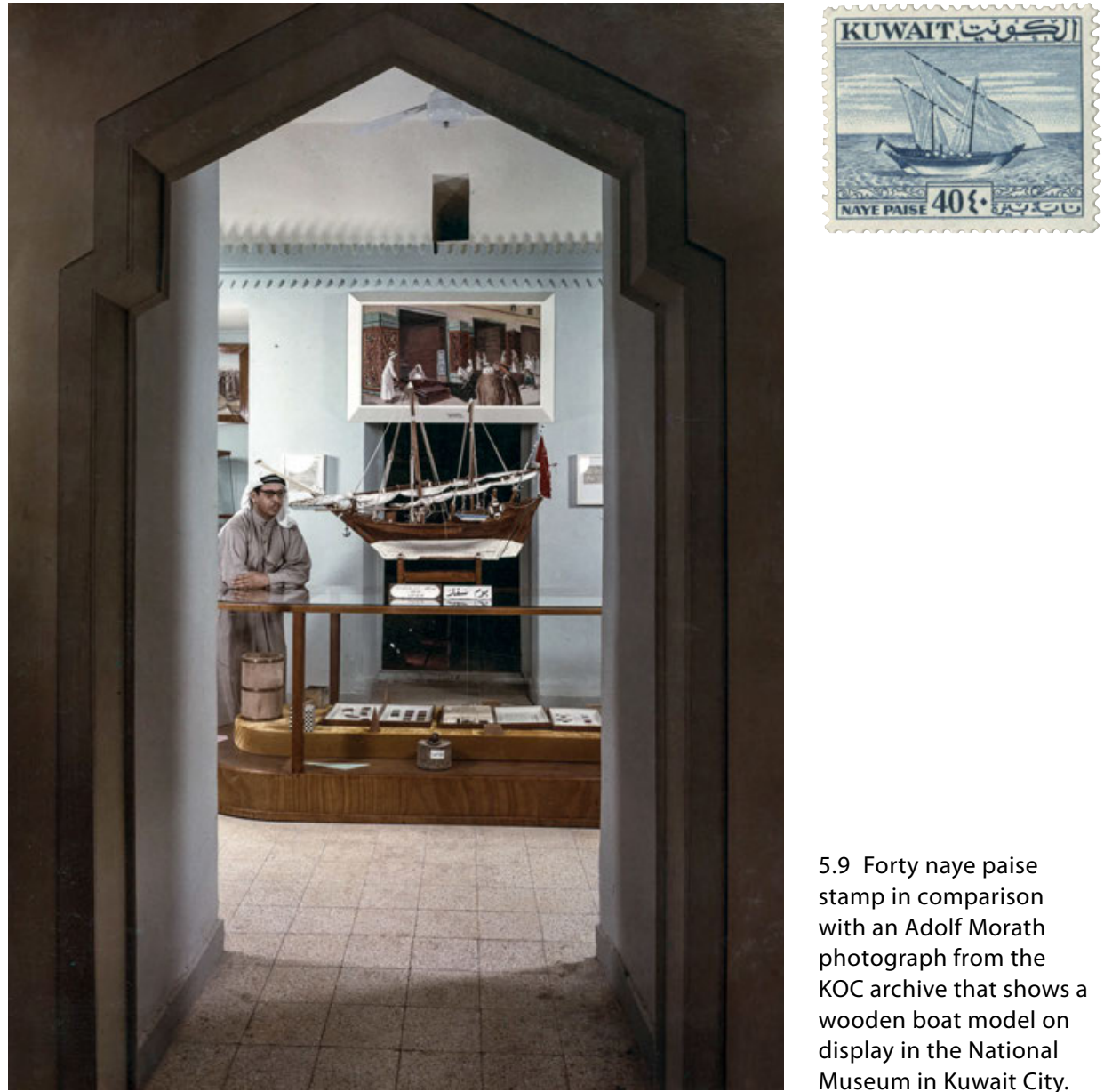

\begin{abstract}
5.9 Forty naye paise stamp in comparison with an Adolf Morath photograph from the KOC archive that shows a wooden boat model on display in the National Museum in Kuwait City.
\end{abstract}

the National Museum, probably similar to the model boat that Morath photographed at the museum. ${ }^{41}$ Like the heritagization process of photographic and urban isolation that turned the town wall gates into heritage vistas, the dhow, both as model and as stamp, is also pictorially decontextualized and severed from its former socioeconomic function.

While the forty naye paise stamp highlights the sea, the dark red fifty naye paise is dedicated to petroleum (fig. 5.10). The stamp shows a very detailed view of the oil-loading

${ }^{41}$ Khaled Alabdulmughni describes the model boat as a boat type called sambūk rather than būm, but Alan Villier notes that the term sambūk was often used to refer to all kinds of sailing vessels, therefore serving as an umbrella term. Khaled Alabdulmughni, "60 Years Since Issuing the Shaykh Abdullah Al-Salem Stamp: Boycotting Israel-Postal Service Nationalization,” al-Būsța (al-Posta), no. 40 (May 2018): 45; Villiers, Sons of Sindbad, 365 (appendix 1: Types of Arab Dhows). 


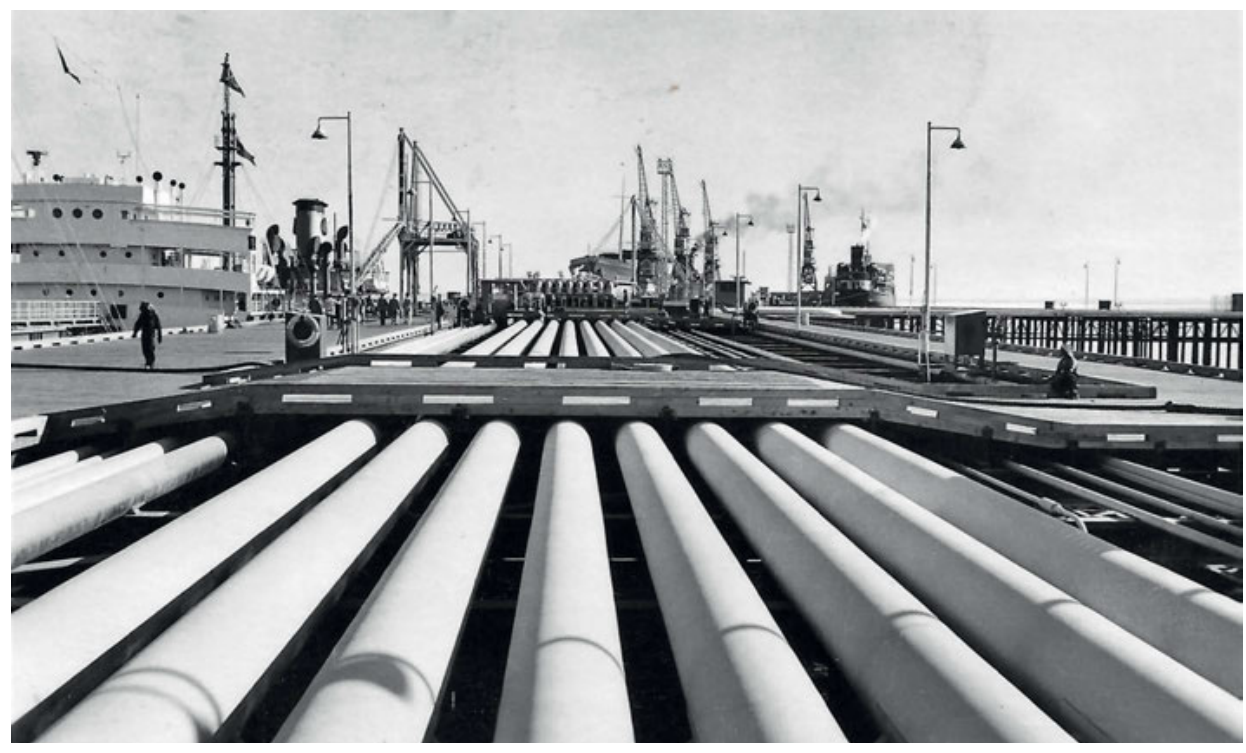

5.10 Fifty naye paise stamp in comparison with undated postcard showing Abdel Razzaq Badran's black-and-white photograph View of Mina al-Ahmadi, the Kuwait Oil Port at Ahmadi, 1952.

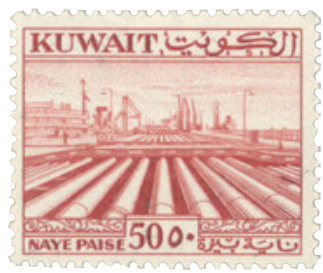

pier at Mina al-Ahmadi, the oil harbor of Kuwait located around forty kilometers south of Kuwait City. Along the jetty, oil tankers are berthed for loading and several cranes rise in the background. The linear perspective of pipelines running along the mile-long pier into the Gulf draws the viewer into the image and toward the vanishing point. Compared with historical photographs, however, the viewpoint indicates that the picture was taken while standing on one of the pedestrian bridges crossing the pipelines and looking landward. Photographs of the oil-loading jetty, often referred to as "the largest oil terminal in the world," appeared in almost every publication and every article on Kuwait and its oil industry at the time. ${ }^{42}$ Kuwaiti collector Ali AlRais and others have established proof that the stamp's photographic template was based on a picture taken by Palestinian photographer Abdel Razzaq Badran, the owner of the famous Studio Badran in Kuwait City, in $1952 .{ }^{43}$ Prior to proliferating as a stamp motif, the image appeared on the cover

${ }^{42}$ C. A. Philip Southwell, “Kuwait," Journal of the Royal Society of Arts 102, no. 4914 (1953): 35.

${ }^{43}$ Abdel Razzaq Badran (1917-2003) was born in Haifa, Palestine, and studied at the Faculty of Applied Arts in Cairo, where he graduated in 1940. Upon moving to Kuwait, he opened a photography studio, Studio 


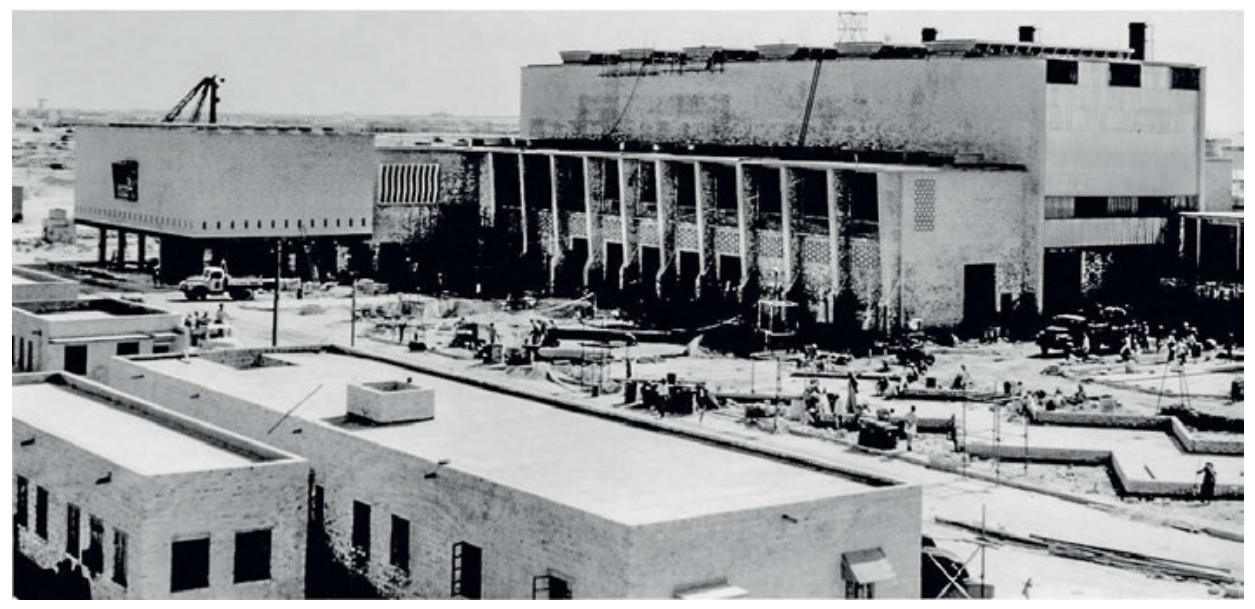

5.11 Seventy-five naye paise stamp in comparison with black-and-white photograph of the power and desalination plant in Shuwaikh, Kuwait City. Undated, photographer unknown.

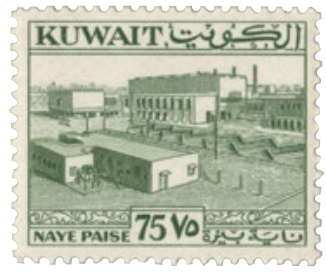

of the Kuwaiti literary monthly al-Bahth (est. 1950) and eventually postcards with this image also circulated. The stamp's level of detail is rare, as stamp designs of that period usually adhered to simplicity and reduction to ensure printing quality and legibility in the miniature format. ${ }^{44}$

Another site of technical progress and infrastructural prowess is celebrated in the green seventy-five naye paise stamp (fig. 5.11). This stamp depicts the compound of the power and desalination plant in the neighborhood of Shuwaikh, a new industrial area southwest of the former Kuwait town wall. As historical photographs show, the plant was directly situated at the seashore (fig. 5.12). ${ }^{45}$ Inaugurated in 1953, the power and

Badran, in Amir Street, which became the first commercial studio for photography in Kuwait. 'Alī G. alRa'īs, "al-Muṣsawir al-futūghrāfī 'Abd al-Razzāk Badrān rāid șuwar al-biṭāāt al-barīdiyya fī l-Kuwayt [The Photographer Abdel Razzaq Badran Is the Pioneer of Postage Stamps Images in Kuwait]," al-Būsța (al-Posta), no. 28 (April 2013); Alabdulmughni, “60 Years Since Issuing the Shaykh Abdullah Al-Salem Stamp," 44.

${ }^{44}$ For mid-twentieth-century discussions on the importance of simplicity in stamp design, see B. G. Harrison, “The Postage Stamp," Journal of the Royal Society of Arts 88, no. 4562 (May 1940): 652; John Easton, "The Design and Manufacture of Postage Stamps in the Commonwealth," Journal of the Royal Society of Arts 110, no. 5066 (January 1962): 116.

${ }^{45}$ In 1951, Ewbank \& Partners-along with the subcontractor John Taylor \& Sons and architects Farmer \& Dark, both of which were also British companies-was appointed to design one of the world's largest power and desalination plants for Kuwait City. On the entangled visual and architectural histories of water 


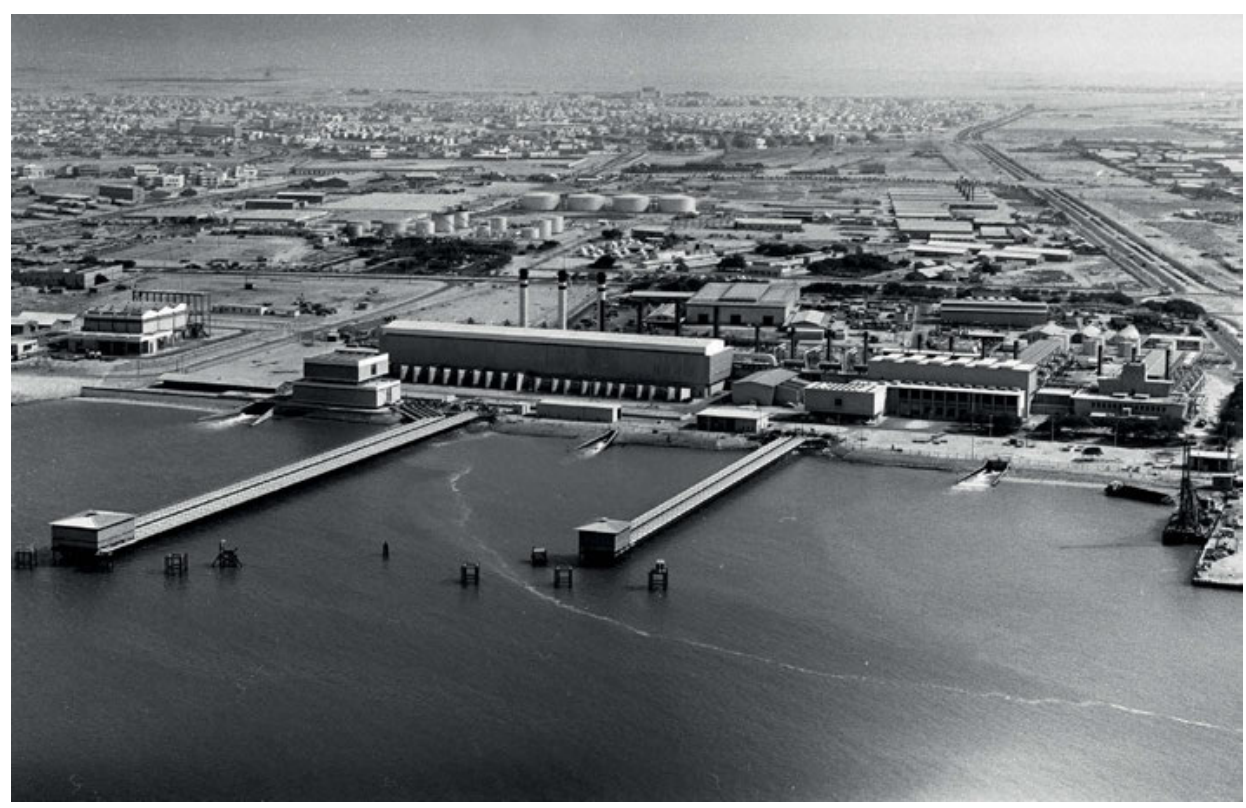

5.12 Black-and-white oblique photograph of the power and desalination plant in Shuwaikh, Kuwait City. Undated, photographer unknown.

desalination plant complex was frequently described as being among the largest plants of its kind in the world and praised for making Kuwait independent of potable water shipments from the Iraqi river of Shatt al Arab for the first time in history. ${ }^{46}$ Photographs of the plant regularly featured in national and international newspapers, publications, and reports on Kuwait. ${ }^{47}$ The stamp's picture shows the turbine hall of the power station with its chimneys in the center and the adjoined cubic main administration building to its left. Extending from the center to the right, the zig-zag lines indicate the water fountain and pond, which was possibly the first pool in Kuwait. The perspective of this image is also noteworthy. The viewer sees the buildings in profile from somewhere high up, almost like a close-up oblique; perhaps the photograph was taken from aboard a big ship docked at

and petroleum in Kuwait, see Laura Hindelang, "Precious Property: Oil and Water in Twentieth-Century Kuwait." In Oil Spaces: Exploring the Global Petroleumscape, ed. Carola Hein (New York: Routledge, 2021), https://doi.org/10.4324/9780367816049-12.

${ }^{46}$ Monroe, “The Shaikhdom of Kuwait," 279.

47 See, for example, A Special Correspondent, "Town Planning in Kuwait: Rebuilding a Middle East Capital," The Times Review of Industry 5, no. 57 (October 1951); William Kitson, "Kuwait's Distillation Plant for Domestic Water," The Times Review of Industry and Technology, December 1951; Southwell, "Kuwait," 36; Monroe, “The Shaikhdom of Kuwait," 278-81. 


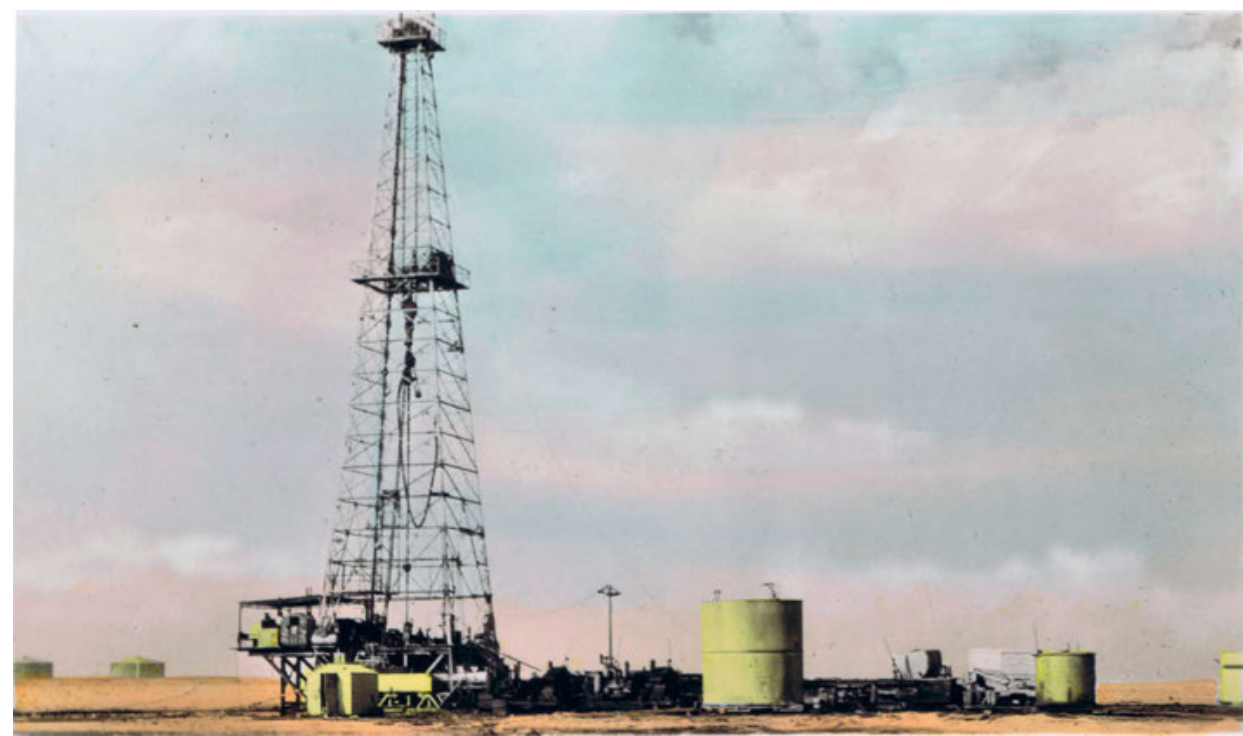

5.13 One rupee stamp in comparison with an undated and hand-colored postcard showing an oil drilling rig in the Burgan Oil Field.

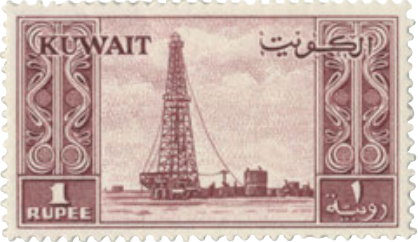

one of the piers close by. Located directly at the shore, the plant was often photographed from the sea to achieve a comprehensive view of the extensive complex.

Next in line, the one rupee stamp forms a group of its own due to the vertical format of its picture: an oil tower in the desert with a small camp next to it (fig. 5.13). While the vertical picture makes up the central part of the stamp, ornamentally decorated fields frame it laterally. The denomination is inserted as pedestals below the ornaments, whereas the country name in Arabic and English hovers in the foreground in the upper part of the stamp, connecting ornament and picture. In general, oil towers such as this one indicated an ongoing prospecting and drilling process that often took months before oil was struck, if the location proved successful at all. Rising many meters above ground, these structures-mobile infrastructures towering over the flat desert-were an impressive sight. According to Khaled Alabdulmughni, the template of this stamp design could have been an undated postcard of a drilling rig in Burgan printed in England. ${ }^{48}$

The fourth and final compositional group comprises the two, five, and ten rupee stamps. Consisting of a framed landscape format without any ornamentation, these

\footnotetext{
${ }^{48}$ Alabdulmughni, “60 Years Since Issuing the Shaykh Abdullah Al-Salem Stamp,” 44.
} 

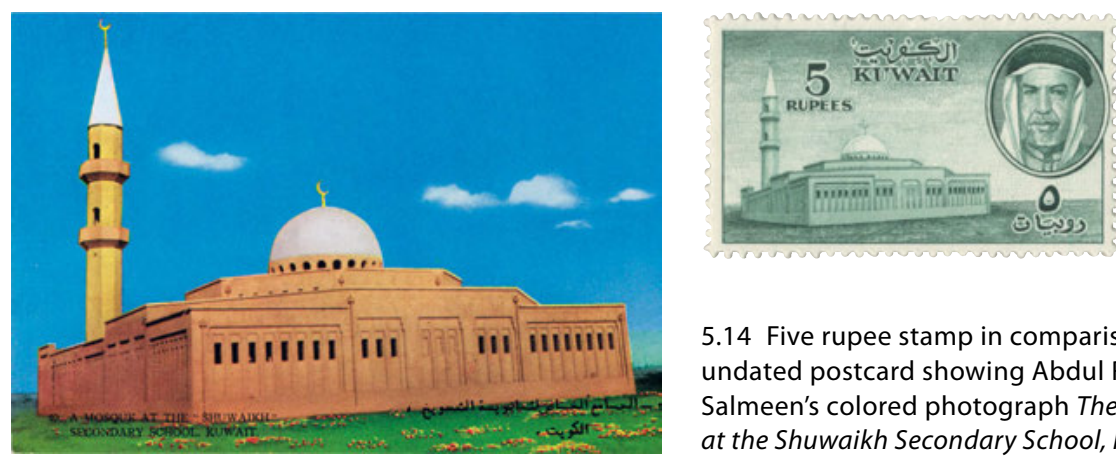

5.14 Five rupee stamp in comparison with undated postcard showing Abdul Redha Salmeen's colored photograph The Mosque at the Shuwaikh Secondary School, Kuwait.

stamps feature a small portrait vignette of Shaykh Abdullah in the upper right corner. The portrait is identical to the portrait of Abdullah used in other stamps in this issue, and the vignettes are set apart from the main picture by a white band. The country name is centered just below the upper edge, and the denominations are located in the upper left corner and the bottom right corner in English and Arabic respectively.

Among all of the stamps in this issue, the two rupee stamp stands out for its bicolored design (see fig. 5.7). A blue and very detailed one-master dhow (a wooden deep-sea vessel called baggala) sails in the foreground. The motif and the color clearly reference the forty naye paise stamp. The rest of the stamp has a sandy color. Here, in the background, are an oil tower and some camp structures, which connect this stamp with the motif of the one rupee stamp and make the two rupee stamp a combination of the forty naye paise and the one rupee stamps. Admired for its usually elaborately carved stern and its longstanding importance for deep-sea trade, the type of vessel presented here was already rare in Kuwait when Alan Villiers visited in 1939 and practically out-of-use by the late 1950s. ${ }^{49}$ Juxtaposing this type of ship with oil infrastructure with this stamp but also the set as a whole created a stark contrast between the historical and modern branches of the Kuwaiti economy, between pearls and petroleum, but given that this transition had taken place under the continuous rule of the Al Sabah, the stamps also demonstrated a certain political continuity.

Shuwaikh Secondary School, which had featured prominently on the government gazette's cover, was also part of the stamp cosmos. The green five rupee stamp depicts the school's mosque (fig. 5.14). The mosque is erected on a square layout and has one minaret and a central cupola capped by a crescent finial (alim). Having room for up to 1,000 worshippers, it rose to fame as the largest one at the time of its completion. ${ }^{50}$ Noteworthy is also this stamp's perspective, with a view insinuating a drive-by mode, as the building's volume blows up and shrinks simultaneously. It is not a central perspective, which the

\footnotetext{
${ }^{49}$ Villiers, Sons of Sindbad, 364 (appendix 1: Types of Arab Dhows).

${ }^{50}$ Alabdulmughni, "60 Years Since Issuing the Shaykh Abdullah Al-Salem Stamp," 44.
} 


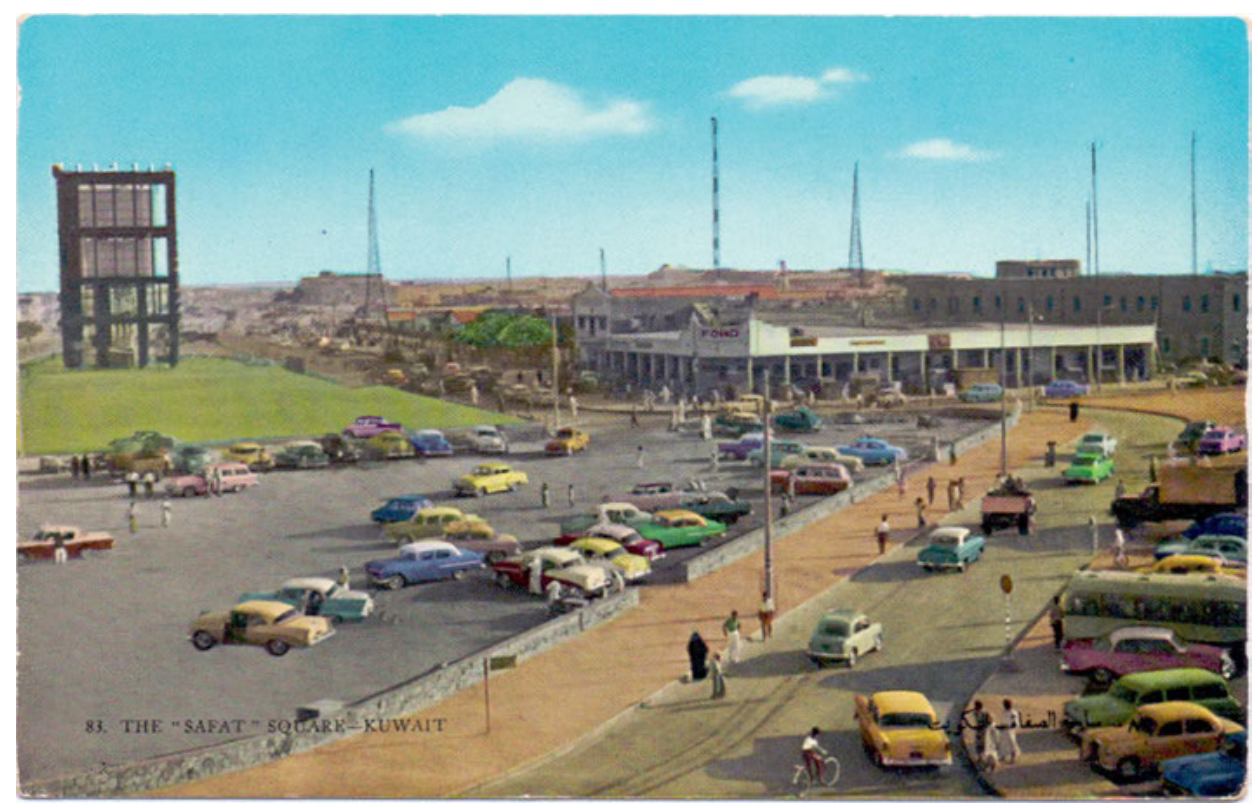

5.15 Ten rupee stamp in comparison with undated postcard showing Abdul Redha Salmeen's colored and retouched photograph The "Safat" Square, Kuwait.

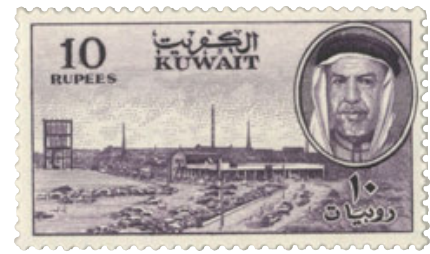

landscape format usually favors, but a little bit off. Despite its peculiarity, the photograph that the stamp was based on circulated also as a color postcard that was published either prior to or after the set of stamps; the postcard names Abdul Redha Salmeen from Basra, who also owned a photo studio in Kuwait, as the photographer. ${ }^{51}$

The last stamp, a purple ten rupee stamp, provides a view of Safat Square (fig. 5.15). Although it recalls the aerial view of Safat Square and its makeshift market stalls that the town planners had frequently published throughout the 1950s, the stamp presents a different image of the square altogether. In the foreground, many cars are either parked or in motion. In the center, at the corner of Safat Square and Fahad al-Salem Street (Jahra Road) and the entrance of Pillar Street, the Ford showcase room, a well-known and often photographed building in the urban landscape of Kuwait, is depicted prominently

${ }^{51}$ Ibid. Alabdulmughni added in a personal conversation that Abdul Redha Salmeen was an Iraqi from Basra who had photo studios there and in Kuwait. He sometimes collaborated with Studio Badran, creating hand-colored postcards from Badran's black-and-white photographs. Email to the author, May 11, 2018. 


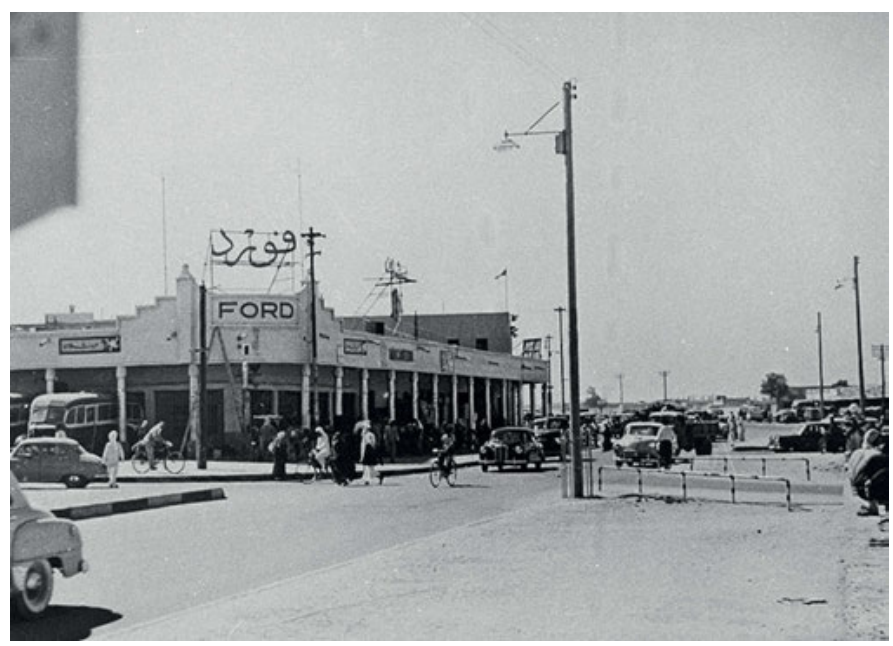

5.16 Black-and-white photograph of Safat Square with the famous Ford showroom. Undated, photographer unknown.

(fig. 5.16). An elevated water tank together with telecommunications antennae also features, forming a dominant vertical element in the urban landscape and highlighting the technological services now available in Kuwait. ${ }^{52}$ An undated postcard with an identical photograph by Abdul Redha Salmeen exists for this stamp (fig. 5.15). ${ }^{53}$ In close comparison, the hand-colored postcard depicts Safat Square with a central green area. The idea of turning the square into lush greens had been stimulated by the new water desalination scheme, but the development project never materialized. ${ }^{54}$ Still, since the beginning of the decade, Safat Square had developed quickly in conjunction with the expansion of Fahad al-Salem Street, which flowed into the square, and had fast become an urban nexus of Kuwait's modernization. Called "Kuwait's Piccadilly Circus" in articles of the time, it was one of the most sought-after locations in Kuwait to open a shop, a showroom, or an office. Safat Square owed its popularity to its historical legacy as a trading locality, to its centrality, and to the availability of parking spaces. ${ }^{55}$ Viewed at street level, Safat no longer looked anything like the obliques that had been taken only a few years earlier as part of the extensive aerial survey.

Characteristic of this 1959 set of stamps overall is the enormous attention to detail and the close similarity of its imagery to existing photographs and photo-postcards.

${ }_{52}$ The water tank belonged to the new water distribution scheme that connected the town to the power and desalination plant in Shuwaikh at four central points. From the tank, potable water was then distributed across town. The British telecommunications company had been one of the first foreign firms to open in Kuwait.

${ }^{53}$ Alabdulmughni, "60 Years Since Issuing the Shaykh Abdullah Al-Salem Stamp," 43-44.

${ }^{54}$ The proposed development of Safat Square is mentioned by Macfarlane, "Planning an Arab Town," 113; John Midgley, "Kuwait," The Sphere, June 16, 1956, 409.

${ }^{55}$ Banks, "Notes on a Visit to Kuwait," 49. 
Given that these photographs and postcards cannot be dated precisely and there is not sufficient Arabic or English archival information on the design process of the stamps, it is not possible to conclude whether it was the stamps or the photographs that popularized the respective Kuwaiti motif. Be that as it may, assuming that the photographs existed prior to the stamp design process, specific photographs of the Kuwaiti built environment (and of Shaykh Abdullah), many of which were taken by local photo studios and also existed as postcard motifs, did serve as templates for a realistic depiction of Kuwait. This shows that the government chose already popularized but very up-to-date photographs of Kuwait. Conversely, considering that the photographs and photo-based postcards were taken (or at least gained in popularity) after the postage stamps were released, it is clear that the stamp designs also promoted certain Kuwaiti vistas and their proliferation in other visual media. Either way (or even both ways), the motifs selected for the stamps circulated in different media as part of a wider visual culture of Kuwait that emerged in the mid-twentieth century in relation to Kuwait's urban transformation and were extremely popular. Consequently, selected elements of Kuwait's recently built environment gained representative status in both popular and political cultures that mutually reinforced each other.

\subsection{Oil Stamps for Petro-States}

During the 1950s, the government of Kuwait developed a new communication infrastructure. Besides the government gazette al-Kuwayt al-Yawm as a mono-directional medium from state to citizen, among the main means of communication were the postal services, which not only connected Kuwaitis locally but also Kuwait with the world.

Given the proliferation of postal communication in the mid-twentieth century, stamps were familiar objects of everyday use and of a widespread visual culture. Firmly glued to a postcard, an envelope, or a parcel, stamps circulated widely in social, spatial, and geographical terms. Especially because of their visual quotidian presence, stamps could "touch the everyday lives (and reflect the attitudes) of both governments and ordinary citizens more readily than grand political rhetoric or state ceremonial" and could become significant political symbols. ${ }^{56}$ The 1959 set of stamps initiated the grand visual infiltration of private space by political symbols and were thus emblematic of the expanding influence of the Kuwaiti government on everyday life and visual culture, as well as on how Kuwait was promoted (inter)nationally. This demonstrates that the state did not only rely on the physical presence of state-initiated infrastructure projects. Rather, the government's negotiation of the distribution of color photographs by the Kuwait Oil Company and its substantial efforts to produce postage stamps with Kuwait (City) motifs underscore the political importance attached to the circulation of updated urban images to Kuwait's visual representations.

\footnotetext{
${ }^{56}$ Jeffery, "Crown, Communication and the Colonial Post," 46.
} 


\section{A Pictorial Travel Guide to the Petropolis Kuwait}

To reconstruct the way in which the Kuwaiti stamps circulated, the 1959 Post Office Guide for Kuwait provides details on all the postage rates for internal and international surface and air mail. ${ }^{57}$ Sending a postcard or a normal letter within Kuwait cost five naye paise and ten naye paise respectively; hence, one or several Shaykh Abdullah stamps were needed. Via airmail, letters to Europe cost sixty naye paise; to Arab countries included in category $\mathrm{A}$, postage started at forty naye paise, a rate that apparently popularized the blue dhow stamp. ${ }^{58}$ However, sending a standard letter to Venezuela, another oil producer, the envelope required at least the one-rupee oil derrick stamp and twenty-five naye paise worth of ruler portrait stamps in order to travel successfully.

While the most frequently used stamps were presumably the smallest denominations and thus the ruler portrait stamps, the heavier the letter or the parcel and the greater the distance the more stamps had to be used in combination to make up the exact postal rate. Postage stamps therefore did not only travel individually but also as a combined display, as preserved envelopes from the period show (fig. 5.17). It can be safely assumed that many colorful and richly illustrated envelopes and boxes left Kuwait for other countries, thereby transporting stamp collages of images of Kuwait to destinations near and far. The potential message of such pictorial postal communication can be illustrated by an example.

When Mr. Wolstencroft, director of the General Post Office in London, visited Kuwait to attend the official ceremony of the postal handover in February 1959, his itinerary listed the following stops: On February 1, Wolstencroft was to meet the acting ruler during the opening ceremony. He would then inspect the new post office at Safat Square. In the afternoon, "a drive around the town and a tour of the Distillation Plant" were planned. For the next day, "lunch at Ahmadi" and afterward visits of a post office and an oil rig were scheduled. ${ }^{59}$ Out of a total of eight scenes or themes depicted on the 1959 set of stamps, Wolstencroft's Kuwait itinerary covered at least four: ruler, Safat Square, distillation plant, and oil rig; maybe even the oil jetty in the harbor of Ahmadi. This description is evidence that the locations and the person depicted on the 1959 set of pictorials displayed a set of officially acknowledged, representative images of Kuwait at the time. As a combined display on an envelope, as a collage of modern Kuwait, the stamps functioned as a mobile miniature travel guide that made the addressee a visitor to Kuwait through images.

In the absence of long-established tourist attractions like the pyramids (Egypt) or Roman ruins (Baalbek in Lebanon), Kuwait confidently drew on sites of current

\footnotetext{
${ }^{57}$ Administration of Posts, Telegraphs \& Telephones, Post Office Department, Post Office Guide (Kuwait: Government Printing Press, 1959).

${ }^{58}$ Neil Donaldson, The History of the Postal Service in Kuwait, 1775-1959 (Bombay: Jal Cooper, 1968$), 12$. Category A included neighboring countries (except Saudi Arabia) like Bahrain, Iraq, but also Jordan, Lebanon, and Syria.

${ }^{59}$ Joe W. Lee, British Postal Agency Kuwait, to Miss D. M. King, General Post Office, January 25, 1959, Transfer of Responsibility for Postal Services, Part 2.
} 
5.17 Airmail cover sent to Germany, January 29, 1961, with two stamps from the 1959 Kuwaiti set.

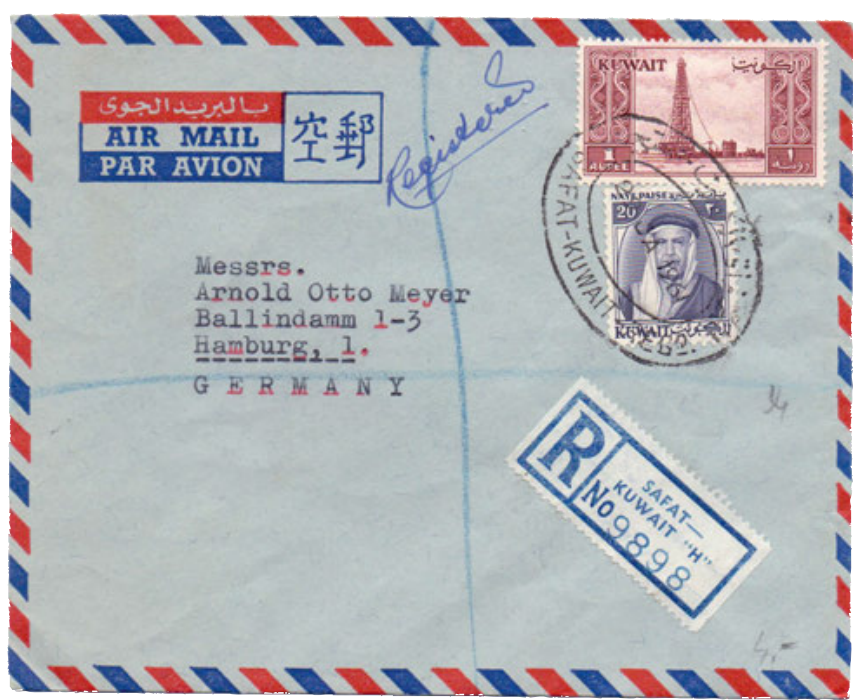

architectural and infrastructural development for its self-promotion. The state could have selected Seif Palace (at least early nineteenth century) or a pre-oil-era mosque; instead it showed the desalination plant and the most recently built mosque among other scenes. These choices suggest that these particular motifs were considered the most positive and attractive representations of the country for the purpose of giving a kind of "philatelic tour," ${ }^{60}$ which was a potential of Middle Eastern pictorial stamps that philatelist Robert Obojski has identified as follows:

Such stamps offer vicarious travel through the length and breadth of the Middle East and its environs-or at least provide a kind of photo album with glimpses of those special tourist attractions that we absolutely must visit in person some day, or, if we have visited them, must never forget. ${ }^{61}$

Postage stamps that show richly illustrated yet realistic locations of a particular country stimulate visual familiarization but also a longing to visit, a kind of place promotion.

However, the pictorial potential of stamps, especially from the MENA region, was not without pitfalls. A large number of stamps from the decolonizing Arab world, with their rich and delicately executed motifs, meandered between confident self-representation by advertising the country in self-chosen pictures and succumbing to the "colonial picturesque." This was, as Middle East historian Donald Reid has argued, "a genre that became popular in other colonial settings throughout the Middle East and beyond" as it drew on orientalist painting and illustrations by displaying "a quaint 'Oriental' land as viewed by

${ }^{60}$ Robert Obojski, “A Philatelic Tour,” Saudi Aramco World 34, no. 1 (1983), accessed January 31, 2021, https://archive.aramcoworld.com/issue/198301/a.philatelic.tour.htm.

${ }^{61}$ Ibid. 
Western romantics and travelers." 62 By relying on the motif of the "colonial picturesque," such stamp sets turned countries with a long and rich history-like Lebanon, Syria, and Iraq-into "open-air antiquities museums." ${ }^{63}$ Using the 1914 Ottoman set as an example, Reid described characteristics he considered typical for this type of stamp: "it has elaborate Arabesque frames, scenic landmarks as subjects, was printed in London, and revives the prominent use of a second language." ${ }^{44}$ Reid's description clearly fits the 1959 Kuwaiti set. This might explain why an influential philatelic magazine even described the 1959 Kuwaiti series as "British Colonial pictorials." ${ }^{65}$ To a certain extent, the extremely detailed, decorated, and colorful Kuwaiti stamps printed in London were also perceived as following the aesthetic of the "colonial picturesque" in a similar way as many other Middle Eastern series.

On closer inspection, however, the Kuwaiti stamps also defy such a categorization. Most motifs display modern, universal infrastructure that strongly distance the stamps from orientalist tropes or the ethnographically inspired black-and-white photography of Bedouins and coral-stone towns of the Arabian Peninsula, which were the historical traveler or tourist motifs emblematic of the region that would soon materialize in openair heritage villages. In turn, the motifs resonated with modernization and development discourse that were fueling the demand for images of progressive infrastructures as symbols of industrial production, mass-consumption, progress, and so on ${ }^{66}$ Moreover, the pervasiveness of development and modernization could be seen in the power to project future progress and change through representations and visualizations that functioned irrespectively of local conditions, representations that embraced a certain international standardization and readability. Such a universal (yet site-specific) reading is present in the 1959 set of stamps, which projected the city-state of Kuwait City as a petropolis, a modern capital city participating in petro-modernity. To project such an image successfully, the photo-realistic templates of architectural-infrastructural sites in Kuwait underwent a process of aestheticization to create images-of-infrastructures that conveyed the enchantment and the petroleum promise of such structures.

\section{Visualizing Infrastructural Stability in Postal Miniatures}

Leaving the dhow and the portrait stamps aside, the remaining six stamps of the 1959 set depict utilitarian structures. These utilitarian structures facilitate the production of water and electricity, they transport crude oil, and house (religious) education systems.

${ }^{62}$ Reid, "The Postage Stamp," 82. For a history of ideas of the "the picturesque" and its use in art and architecture, see John Macarthur, The Picturesque: Architecture, Disgust and other Irregularities (Abingdon: Routledge, 2008).

63 Reid, “The Symbolism of Postage Stamps," 243.

${ }^{64}$ Ibid., 233-34.

65 “Stamp News in Brief: British Commonwealth," Gibbons' Stamp Monthly 32 (February 1958).

${ }^{66}$ Escobar, Encountering Development, 5. 
They also depend on motorized transportation and modern communication networks, and they connect humans and nonhuman matter. These structures have a defined physical form, are spatially fixed, and are, to various decrees, site-specific. They truly are "infrastructure" in the sense of recent (mostly anthropological) research loosely referred to as the "infrastructural turn" or "infrastructural studies." 67

These structures, which exist(ed) somewhere in Kuwait, were translated into stamps as "pictures-of-infrastructure." The process at play was not only depiction but also beautification: to become images, the structures were colored, framed with abstract or arabesque ornaments and with Arabic and English script, and, partly, combined with Shaykh Abdullah's portrait vignette. The stamps were just as colorful as the KOC's color photography, but instead of color-highlighting specific surfaces and materials, the whole scenes were dipped in monochrome color. This pictorial transformation united the disparate structures and sites into one set of stamps of a similar aesthetic. On the stamps, the larger infrastructural networks (e.g., water supply) were represented through built forms-architectural or structural configurations-that stressed their site-specific material presence in visually conceivable forms. The photo-realistic style of depiction and the extremely skillful and detailed execution in the technique of etching enhanced the visual credibility of the structures' physical presence. In the absence of human users or traces of work processes, the compositions and motifs emphasized the visual representationality of the completed structures. We see here what Timothy Mitchell has described as characteristic for modernity: the making of reality as world-as-picture based on the "distinctive imagination of the real" in images. ${ }^{68}$

By turning infrastructure into colorful miniature pictures, the original (technological, religious, urban, infrastructural) function of the structures was discarded. The question of whether and how these infrastructures functioned, and why and how they connected to humans or non-human matter, was left "out of the frame." As images they work in a similar way to the architectural "white elephants" that Hannah Appel describes for Equatorial Guinea, where oil revenues help finance spectacular buildings that are, site-specifically, completely dysfunctional-their prime function is to highlight that something, anything, is happening. ${ }^{69}$

Yet, the projects pictured were not hollow promises. All infrastructural constructions depicted on the 1959 stamps had been built and completed throughout the 1950s and

\footnotetext{
${ }^{67}$ Brian Larkin offers the following definition: "Infrastructures are built networks that facilitate the flow of goods, people, or ideas and allow for their exchange over space. As physical forms they shape the nature of a network, the speed and direction of its movement, its temporalities, and its vulnerability to breakdown. They comprise the architecture for circulation, literally providing the undergirding of modern societies, and they generate the ambient environment of everyday life." Brian Larkin, "The Politics and Poetics of Infrastructure," Annual Review of Anthropology 42 (2013): 328.

68 See Mitchell, “The Stage of Modernity," 16.

${ }^{69}$ Hannah C. Appel, "Walls and White Elephants: Oil Extraction, Responsibility, and Infrastructural Violence in Equatorial Guinea," Ethnography 13, no. 4 (2012).
} 
thus during Shaykh Abdullah's rule. ${ }^{70}$ They were solid proof of Kuwait City's urban transformation and therefore of political, economic, and technological progress and success. They were part of the petroleum promise because they expressed the idea that, with more oil, even more modernization would materialize. Through their appearance on the first state-issued stamps, these projects were integrated into the pictorial imagination and visual representation of the state. This served to transfer the positive associations of the city's development onto the political system of Kuwait and the reign of Abdullah and the Al Sabah. This infrastructure-as-image functioned through an effect that anthropologists Penny Harvey and Hannah Knox have described as the "enchantments of infrastructure."71 They argue "that it is not in spite of unruly processes that infrastructures emerge as a form of social promise, but rather that it is through the experiences of life within and alongside unstable forces that infrastructures gain their capacity to enchant." 72 In the case of Kuwait, the completed infrastructural projects materialized as soothingly stabilizing forms in an environment of the utmost transformation of all sectors of life-and first and foremost of the built environment. They gained even more stability because they were present both physically as part of the built environment and as recurring pictures (stamps, postcards, photographs). Consequently, the 1959 set of stamps was successful in encapsulating a dominant narrative of material stability that was to become associated with the political stability and national unification orchestrated under Shaykh Abdullah that climaxed in the 1961 independence. Stability was not created through historical continuity of physical space but by displaying the present (the newly rebuilt environment) as a projection of the positive future image of Kuwait in an iridescent way.

\section{Petrophilately ${ }^{73}$}

State sovereignty and political legitimacy are highly dependent on a convincing visual or symbolic regime. ${ }^{74}$ For example, recent studies have focused on political visual culture as a driving force in the processes of state formation in the modern Middle East. ${ }^{75}$ However,

\footnotetext{
${ }^{70}$ It is of course possible that the exact oil derricks had in fact been built prior to 1946 to facilitate the early stage of petroleum extraction. However, this does not influence the overall argument.

${ }^{71}$ Penny Harvey and Hannah Knox, “The Enchantments of Infrastructure”, Mobilities 7, no. 4 (2012).

72 Ibid., 525.

${ }^{73}$ In the following, MiNo. refers to the catalog number of the stamps in Michel Gulf States Catalogue 2013, 2nd ed. (Unterschleißheim: Schwaneberger Verlag, 2012). SG SofW No. refers to the catalog number of the stamps in Stanley Gibbons, ed. Stamps of the World 1978, 43rd ed. (London: Stanley Gibbons, 1977).

${ }^{74}$ Gabriella Elgenius, Symbols of Nations and Nationalism: Celebrating Nationhood (New York: Palgrave Macmillan, 2011), 4.

${ }^{75}$ On the role of visual culture in relation to national politics, see Lina Khatib, Image Politics in the Middle East: The Role of the Visual in Political Struggle (London: I. B. Tauris, 2013); Lisa Wedeen, Ambiguities of Domination: Politics, Rhetoric, and Symbols in Contemporary Syria, rev. ed. (Chicago: University of Chicago Press, [1999] 2015). On visual culture as tool of nation-building, see Eric Davis and Nicholas Gavrielides,
} 
the social and political sciences still struggle to firmly incorporate visual approaches into their toolboxes. ${ }^{76}$ In art history, the formation of certain reoccurring motifs that draw their aesthetic as well as political legitimacy from the Zeitgeist of the era has been studied as "political iconography." ${ }^{77}$ Martin Warnke, one of the advocates of political iconography, suggested that it is ruling elites who are most dependent on some form of visual representation as self-affirmation and expression of political stability. ${ }^{78}$ For the Kuwaiti postage stamps of 1959, the state used architectural and infrastructural motifs, as well as the portrait of Shaykh Abdullah for its pictorial self-representation toward potential visitors, its citizens, and other states. Judging from the high frequency of visual representations of oil-related motifs, which also appeared on the stamps of other oilproducing countries during the 1950s and 1960s, Kuwaiti postage stamps were a pivotal visual media for displaying Kuwait as a petro-state and for communicating this status to other (petro-)states.

The petroleum-industrial complex is explicitly referenced in three Kuwaiti stamps from 1959: the one and two rupee stamps (oil derricks) and the five naye pase stamp (the Mina al-Ahmadi oil harbor with its pipelined pier). In addition, less immediately recognizable petroleum experiences are depicted on other stamps. For example, the seventy-five naye paise stamp features the gigantic power and desalination plant, which was paid for by oil revenues and fueled by waste gas from the Burgan Oil Field, and the ten rupee stamp shows Safat Square, the traffic nexus of the city and a place to showcase cars-for example in the famous Ford showroom. ${ }^{79}$ Cars were also indispensable for reaching the new secondary school, whose characteristic mosque can be seen on the five rupee stamp. As part of the scheme of suburbanization and private motorization initiated by the first master plan, the Shuwaikh campus lay far outside the historical town

\footnotetext{
"Statecraft, Historical Memory, and Popular Culture in Iraq and Kuwait," in Statecraft in the Middle East: Historical Memory and Popular Culture, ed. Eric Davis and Nicholas Gavrielides (Miami: Florida International University Press, 1991).

${ }^{76}$ For debates taking place in Germany, see Marion G. Müller, "Politologie und Ikonologie: Visuelle Interpretation als politologisches Verfahren," in Schwelling, Politikwissenschaft als Kulturwissenschaft; Klaus von Beyme, "Why Is There No Political Science of the Arts?", in Pictorial Cultures and Political Iconographies: Approaches, Perspectives, Case Studies from Europe and America, ed. Udo J. Hebel and Christoph Wagner (New York: De Gruyter, 2011).

77 The concept of "political iconography" draws on Erwin Panofsky's theory of iconography and iconology of the 1930s. See Uwe Fleckner, Martin Warnke, and Hendrik Ziegler, eds., Handbuch der politischen Ikonographie, 2 vols. (Munich: C. H. Beck, 2011).

${ }^{78}$ Martin Warnke, "Politische Ikonographie: Hinweise auf eine sichtbare Politik," in Wozu Politikwissenschaft? Über das Neue in der Politik, ed. Claus Leggewie (Darmstadt: Wissenschaftliche Buchgesellschaft, 1994), 170. Also, Klaus von Beyme suggests that "symbolic politics-which iconology analyzes-were, from a historical point of view, most powerful as long as the ruling ones possessed extended decision-making authority." Klaus von Beyme, "Politische Ikonologie der modernen Architektur," in Schwelling, Politikwissenschaft als Kulturwissenschaft, 370 (author's translation).

${ }^{79}$ On the power and desalination plant, see A Special Correspondent, “Town Planning in Kuwait," 91.
} 
center and at driving distances from most newly built neighborhoods. Even as dhows subsequently became symbols of the country's maritime past (for example in Kuwait's national emblem), they also reference one of the pre-industrial local uses of bitumen or tar for sealing boats given its water-repelling qualities. Therefore, most of the stamps relate either directly or indirectly to petro-modernity.

Exploring (the history of) petroleum by flipping through a stamp album or looking at the Kuwaiti set as a travel guide, viewers were able to be comfortably at home and far away from the dirty and even dangerous oil fields, yet traveling in images. Over the decades, something like a "petrophilately," the philatelic study of oil-related stamps, developed among collectors. In a 1988 article in the oil company magazine Saudi Aramco World, stamp collector Raymond Schuessler explained that petrophilately not only included motifs related to the modern petroleum industry and petroleum-based products but also encompassed pre-modern uses of oil for shipbuilding, religious practices, and medicine. ${ }^{80}$ Philatelists agree that the Republic of Azerbaijan was the first country to issue postage stamps with petroleum-related motifs: first, in 1919, two stamps depicting the mystical "Temple of Eternal Flames," which referred to the Zoroastrian oil fire cults, and then, two years later, a stamp showing for the first time oil infrastructure in the form of an oil well. ${ }^{81}$

Throughout the 1950s and 1960s, petroleum, especially in the form of large-scale oil infrastructure, became a frequent, somewhat universal motif of postage stamps. At first, Arab countries were not prominently represented. The presumably earliest article from 1954 on what was later called "petrophilately" discusses the hierarchy of oil producers and their philatelic presence based on a survey of twenty-one oil stamps from various countries:

The U.S.A. has been, and still is, by far the most important oil-producing country. In recent years, however, an increasing contribution has come from Venezuela and countries in the Middle

\footnotetext{
${ }^{80}$ Raymond Schuessler, "Petrophilately," Saudi Aramco World 39, no. 1 (1988), accessed January 31, 2021, https://archive.aramcoworld.com/issue/198801/petrophilately.htm. When Schuessler coined the expression "petrophilately" in the late 1980s, the Petroleum Philatelic Society International already existed. Founded in 1974, its website mentions the heightened awareness of the political and economic implications of petroleum in the 1970s as reasons for creating the study group. With "the purpose of advancing the philately of the oil, natural gas and petrochemical industries," the society is an official study unit of the American Topical Association and an affiliate of the American Philatelic Society. Today, it is the leading authority on petroleum-related philately. See the website Petroleum Philatelic Society International, accessed January 31, 2021, https://www.ppsi.org.uk/. This underlines that "petrophilately" resonated with a large interest group worldwide.

${ }^{81}$ Azerbaijan 1919, SG SofW Nos. 9-10, showing the "Temple of Eternal Flames." Two year later, the first stamp displaying modern petroleum infrastructure, here an oil well, was issued (Azerbaijan 1921, SG SofW No. 12). See "The Philatelist's Story of Oil," Stamp Collecting, July 23, 1954, 611; “Oil Stamps," Saudi Aramco World 13, no. 8 (1962), accessed January 31, 2021, https://archive.aramcoworld.com/issue/196208/oil.stamps. htm.
} 
East... . As far as the philatelist is concerned, however, these vast oil riches [in the Middle East] are represented by a set of two stamps, showing oil derricks in Iraq. ${ }^{82}$

Despite omitting the 1953 definitive issue of Iran, which showed an oil derrick set against a city's silhouette with protruding minarets, this statement is still not surprising given that many Middle Eastern states had either not yet found oil or were still using overprinted British stamps. From the 1950s onward, however, this changed rapidly: after Iraq (1941) and Iran (1953), Kuwait (1959) was the next country to issue petroleum-related stamps, quickly followed by the United Arab Republic (1959), Saudi Arabia (1960), Jordan (1961), Qatar (1961), Libya (1961), Abu Dhabi (1964), Dubai (1966), Syria (1969), and Muscat and Oman (1969). ${ }^{83}$ Only a decade after the 1954 article on petrophilately, a substantial body of oil stamps had been issued in the MENA region. This dissemination of oil stamps reflected the rise of Arab oil producers on an international level, irrespective, in a way, of whether it was an "oil rich" or "oil poor" Arab state, or whether a state was fully or only partially dependent on oil revenues, or in fact in charge of oil operations. This proliferation of oil stamps resonated with the fact that "the oil phenomenon has cut across the whole of the Arab world... . Oil as the primary source of rent in the Arab region has generated various secondary rent sources [like pipeline royalties] to other non-oil Arab states." ${ }^{84}$ This meant that most Arab states were involved in the oil economy in one way or another.

A comparative analysis of these oil stamps shows that, when only one petroleumrelated stamp was part of a country's regular set of definitives, the oil derrick was the

82 “The Philatelist's Story of Oil," 613. The Iraqi stamps referred to are: Iraq 1941, MiNo. 115 (derricks) and Iraq 1955, MiNos. 188-90 (King Faisal II, industry and technology [derricks]). This article was also reprinted as a small booklet: Petroleum Information Bureau, The Philatelist's Story of Oil (London: Petroleum Information Bureau, 1960).

${ }^{83}$ This list is intended to be illustrative rather than exhaustive. It indicates the issue of the first stamp depicting an image of oil infrastructure by a (colonized or independent) country. Iraq 1941, definitives, MiNos. 115-16 (oil derricks); Iran 1953, definitives, SG SotW Nos. 999-1002 (oil derrick and mosque); Iran 1953, air mail, SG SotW Nos. 1003-06 (oil well and mosque); Iran 1953, commem., SG SotW Nos. 1007-11 (2nd anniv. of nationalization of oil industry; crude oil stabilizer, pipelines, view of Abadan, super fractionators); Kuwait 1959, definitives, MiNos. 137, 139 and 140; U.A.R. (Syria) 1959, commem., SG SotW No. 697 (inaug. of oil refinery); Saudi Arabia 1960-62, definitives, MiNos. 87-102 (oil refinery, Ain Dair); Jordan 1961, commem., SG SotW Nos. 502-03 (inaug. of Jordanian petroleum refinery); Qatar 1961, definitives, MiNos. 33-34 (derrick); Libya 1961, commem., SG SotW Nos. 263-65 (inaug. of first Libyan petrol pipeline [Zelten Field and Marsa Brega Port]; Abu Dhabi 1964, definitives, MiNos. 10-11 (derrick with camels); Dubai 1966, air mail, MiNos. 193-207 (anniv. of oil exploration in the Persian Gulf on March 15, 1964; various steps in the oil prospecting and production process); Syria 1968, commem., SG SotW Nos. 987-88 (pipeline); Syria 1968, definitives, SG SotW Nos. 1009-1015 (oil derrick); Muscat and Oman 1969, commem., MiNos. 107-09 (1st mineral oil shipment in July 1967; oil port and oil tanks in Mina Fahal, derrick in the desert). Surprisingly, Bahrain did not issue a single oil-related stamp, despite being the first of the Arabian Gulf countries to strike oil in 1932.

${ }^{84}$ Hazem Beblawi, “The Rentier State in the Arab World," in Beblawi; Luciani, The Rentier State, 59-62, here 62. 
favorite motif. When several stamps illustrating different petro-industrial aspects were issued, these were usually issued as part of a commemorative set, and not a definitive one-for example, to mark the anniversary of an important oil exploration or the inauguration of an oil port. Motifs of oil infrastructure and petroleum-related events on Arab countries' stamps became so common that the power of writing a country into the global history of oil through these forms of visual references-Walter Benjamin called them "business cards" of states-cannot be underestimated.

Oil stamps certainly became a pictorial currency in the Arab world, but not only there. By 1962, in light of rapidly increasing successful oil explorations worldwide, forty-six oilproducing and oil-refining countries (like Curaçao in the Dutch West Indies) across the world had issued a total of 451 "oil stamps." ${ }^{85}$ Many of these states relied on such typical oil infrastructure motifs as the oil derrick in order to highlight their relationship with petroleum on stamps. The oil derrick thereby became emblematic of petro-states globally.

\section{The Oil Derrick as Political Iconography}

As the preferred iconography of oil, the symbol of the oil derrick was not just a convenient icon. When one considers other fossil energy landscapes, like the former coal-mining region of the Ruhr area in western Germany, one notices that the hidden or invisible presence of subterranean deposits of coal (or oil) is indicated and made visible by vertical infrastructures, even after the coal (or oil) itself is long gone. ${ }^{86}$ Headframes, oil derricks, and pumpjacks spatially locate and physically indicate the (former) availability of the fossil materials while towering over the landscape and are clearly visible for miles-for instance set against the flat desert of Kuwait, as historical photographs show (fig. 5.18). Apart from their indicator function, such structures are of course crucial for the extraction process that targets the precious subterranean riches. The oil derrick is therefore complicit in forms of vertically materialized dominance and power in a similar way to other structures with a heightened vertical presence, such as towers, minarets, bell and church towers, and of course skyscrapers.

Both Iran and Qatar even explored the analogy of the slender oil derrick (or tower) and the minaret of a mosque by combining the two motifs in one stamp design. While the Iranian stamp from 1953 places the oil tower in the foreground, framed and echoed by domes and minarets in the background (fig. 5.19), the first definitive Qatari issue includes one stamp with an oil derrick and another one with a one-minaret mosque (figs. 5.20a, 5.20b). The two Qatari compositions look so alike that one needs to look

\footnotetext{
${ }^{85}$ See "Oil Stamps." In 2011, there were ninety-eight oil-producing countries; see Reyna and Behrends, "The Crazy Curse and Crude Domination," 4.

${ }^{86}$ See Roland Günter, "Die politische Ikonographie des Ruhrgebietes in der Epoche der Industrialisierung," in Architektur als politische Kultur: Philosophia practica, ed. Hermann Hipp and Ernst Seidl (Berlin: Dietrich Reimer, 1996), 215.
} 
5.18 Black-and-white photograph titled Burgan. Skidding a Rig, 1949. Photographer unkown.

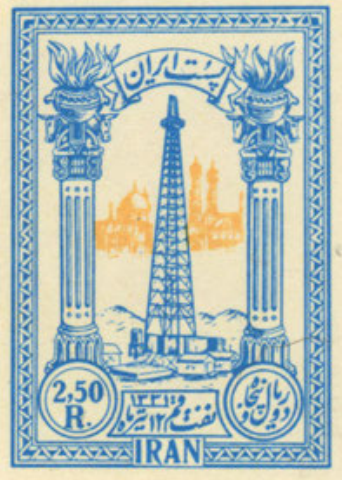

5.19 Two-and-a-half rial stamp showing an oil derrick (blue) in the foreground and a cityscape with a mosque and minarets (yellow) in the background. This stamp is part of the 1953 Iranian issue to commemorate the discovery of oil at Qom, issued February 20, 1953.

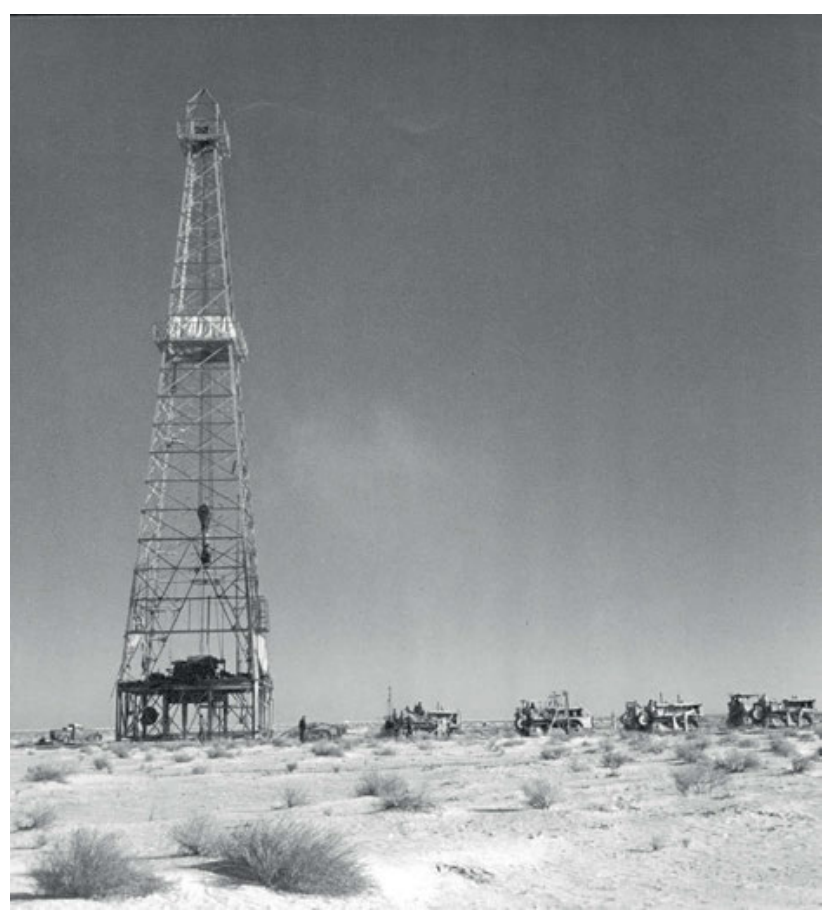

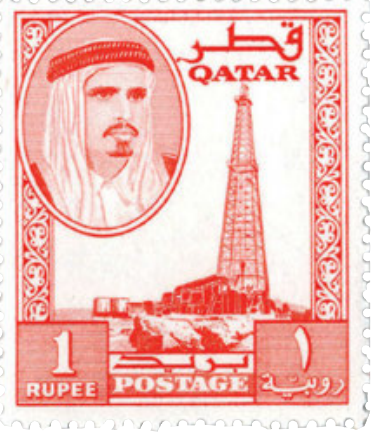

5.20a Red one rupee stamp showing an oil derrick from Qatar's first set of definitives, issued September 2, 1961.

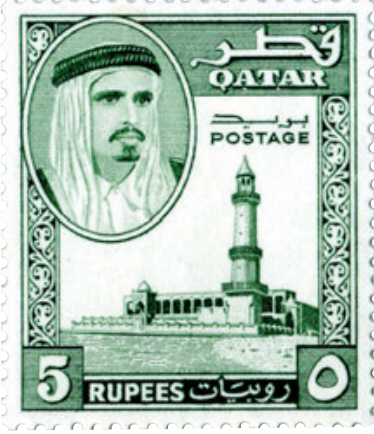

5.20b Green five rupee stamp showing a mosque from Qatar's first set of definitives, issued September 2, 1961. 

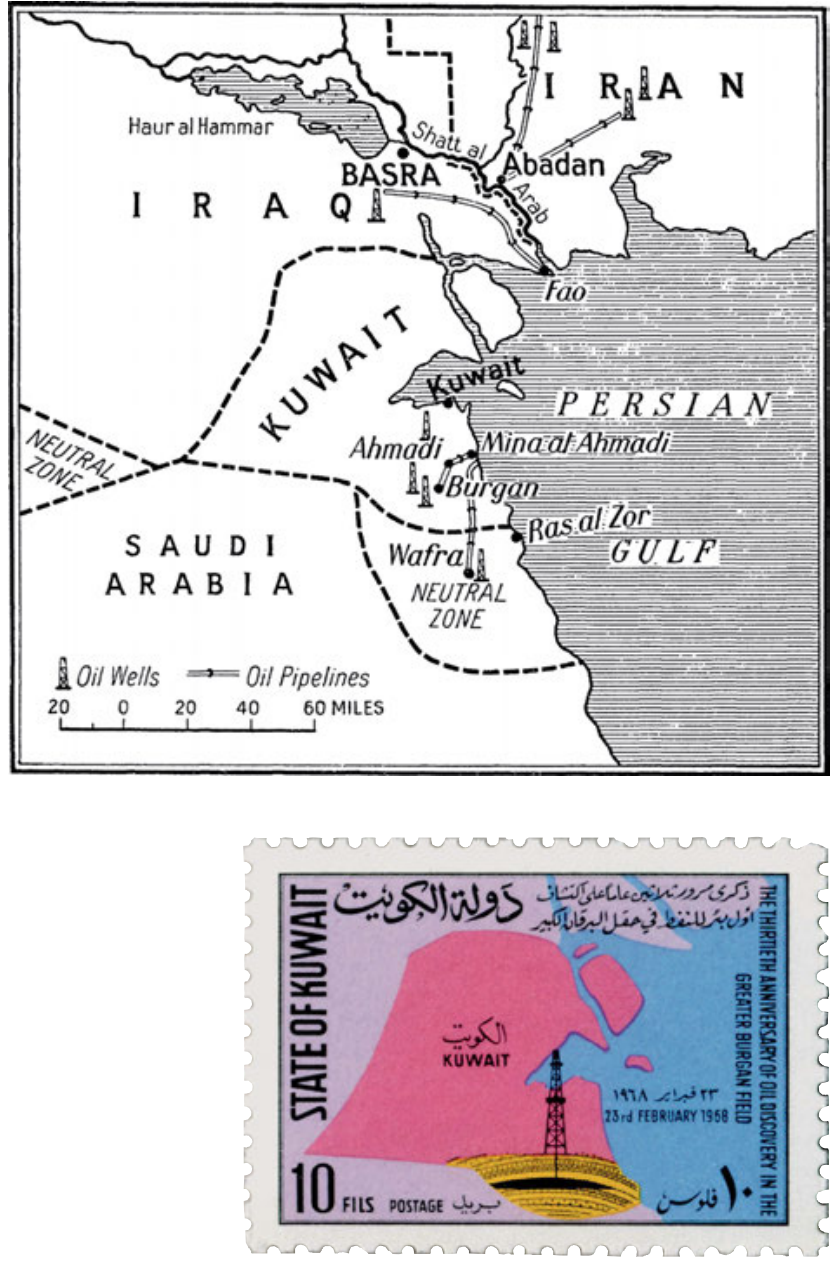

5.21 Map of Kuwait in the journal International Affairs, July 1954, with Kuwait's oil fields marked using an oil derrick icon.

\subsection{Commemorative} stamp issued in set of two on the occassion of the 30th anniversary of the discovery of oil in the Greater Burgan Field, February 23, 1968.

closely to recognize the difference. ${ }^{87}$ These typologies result, of course, from functional demands like audibility of sound (mosque) or the length of drill bits (oil derrick), yet the outstanding vertical visibility conveys more than just its functionality.

${ }^{87}$ Iran 1953, definitives, SG SotW Nos. 999-1002 (oil derrick and mosque); Qatar 1961, definitives, MiNos. 33-34 (derrick) and 35-36 (mosque). Interestingly, the visual juxtaposition and comparison of an oil rig and a mosque also features prominently in The Third River, an Iraq Petroleum Company documentary from 1951; see Damluji, "Petroleum's Promise," 141. The iconography of the infrastructural tower encountering the religious tower (minaret or church tower) is also relevant to the political iconography of the coal mine area of the Ruhrgebiet in the West of Germany. See Günter, "Die politische Ikonographie des Ruhrgebietes in der Epoche der Industrialisierung," 213-15. 
5.23 Kuwait Airways poster of Kuwait, ca. 1960, designed by Alan Gauthier, printed by La Vasselais, Paris. $90 \times 60 \mathrm{~cm}$, poster on linen.
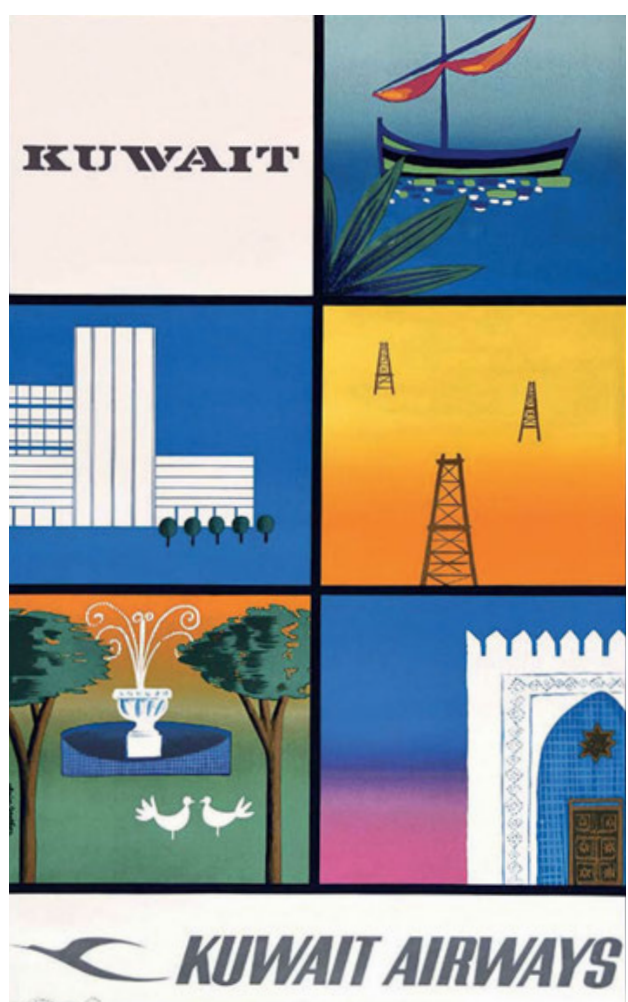

In search of other visual outlets in which the iconography of the oil derrick plays a role, cartographic representations are of relevance. Since the mid-twentieth century the oil derrick has often appeared as a pictogram, a simplified graphic picture, that, according to most map keys, indicates the same universal message: that a country (or a foreign company) is tapping oil deposits in a particular location (fig. 5.21). This combination of motifs, of Kuwait's map and the oil derrick, eventually even emerged as stamp design, commemorating in 1968 the discovery of oil at Burgan (fig. 5.22) ${ }^{88}$ Integrated into both postage stamps and country maps, the oil derrick became an essential element of the "pictorial language of world traffic" (Aby Warburg) and the political iconography of petro-states.

In the 1970s, during the so-called oil crisis, even Arab Homeland maps contained oil infrastructures "for the celebration of oil as a sign of modernization and prosperity" ${ }^{89}$ Although many oil industries were not yet nationalized, OPEC's oil embargo had

\footnotetext{
${ }^{88}$ Kuwait 1968, commem., MiNos. 372-73.

${ }^{89}$ The map that Zayde Antrim discusses was published in al-Arabī in 1974. Zayde Antrim, Mapping the Middle East (London: Reaktion, 2018), 246-48 and fig. 76.
} 


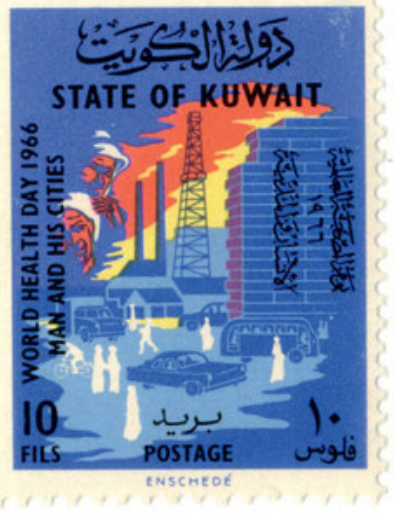

5.24 Commemorative stamp of the 1966 World Health Day with an oil derrick immersed in the industrial cityscape, issued April 7, 1966.

demonstrated the ultimate power these oil-producing countries nevertheless held over the petroleum-dependent world by turning the tap off. To incorporate petroleum icons into cartographic representations of Kuwait equally projected the country within a world interconnected by flows of petroleum.

During the state formation process of the 1950s, the government of Kuwait began using the oil derrick in various visual material issued by the state. Apart from the 1959 stamps, it was used as part of the cover design of the government gazette, and for posters of the state-owned Kuwait Airways, which advertised the country as a travel destination in the 1960s (fig. 5.23). Again and again, the oil derrick appeared in combination with other large modern architecture and infrastructure. It even appeared prominently-and somewhat ironically from today's perspective-on the 1966 World Health Day stamp issued by Kuwait that, which was themed "Man and His Cities," as integral part of the urban landscape (fig. 5.24).$^{90}$ While the symbol of the oil derrick in combination with maps and aerial views also indicated the geospatial location of oil production, in visual outlets like the poster and the gazette, the oil derrick manifested as the central element of the new political iconography of the petropolis of Kuwait that symbolically "nationalized" petroleum.

Through its oil-themed stamps, Kuwait aligned itself firmly with the growing number of oil-producing countries worldwide, other petro-states. Their usually affluent image and status was expressed in the visual business cards of oil-themed stamps. Given that Kuwait was the third Middle Eastern country to produce oil stamps and given that the 1959 definitive (pictorial but not commemorative) set included three different oil-infrastructure stamps, it is clear that the government of Kuwait fully and proudly indulged in the image of the petro-state that many other (Arab) oil producers subsequently followed, or even copied, although in an attenuated style. In particular, the 1959 Kuwaiti set's influence is

\footnotetext{
${ }^{90}$ Kuwait 1966, commem., MiNos. 315-16.
} 
visible in Qatar's 1968 definitive issue, which used almost identical motifs: the ruler, a dhow, a desalination plant, an oil port, a mosque, and the town square. ${ }^{11}$

\subsection{Absences in the Pictures of Development}

In a paradoxical way, in the mid-twentieth century, while lived petro-modernity was gradually becoming inevitable, crude oil was increasingly absent from visual representations, almost becoming conspicuous in its invisibility. Natural phenomena like gushers (sudden eruptions of raw oil) and oil fires were sometimes captured on photographs, but such iconographies of oil quickly ceased to be shown as they came to signify inefficiency in oil production. ${ }^{92}$

The early political iconography of Kuwait was marked by other, even more decisive absences. In the 1959 set, except for the portrait of Shaykh Abdullah, none of the stamps depicted people-even though many of the sites would have normally included workers (the oil port), seafarers (the dhow), believers (the mosque), and shoppers and pedestrians (Safat Square), to name just a few. Given the extreme richness of detail in all of the 1959 pictorial stamps, it would have been easy to include a person next to the mosque or in the vicinity of the desalination plant, who would have been recognizable as such despite the small size of the postal miniatures. Only when comparing the ten rupee stamp of Safat Square with its postcard template can some small lines besides the cars extending from the foreground be identified as graphic abbreviations of people; however, only viewers who are familiar with the postcard version of the image will see them. Then again, if the postage stamps are considered as a continuation and translation of photographic images into another visual media, maybe the orientalist tradition of depopulating urban spaces and landscapes that manifested itself in the early photography of the Middle East also resonated here..$^{33}$ In any case, the 1959 set of Kuwaiti stamps renders ordinary people invisible and focuses on the representation of Shaykh Abdullah instead.

The infrastructural forms that took center stage in providing physical and visual evidence of the materialization of the emerging state (the provision of water and new educational institutions, for example) were strongly tied to the portrait of Shaykh Abdullah through the stamps' composition (country name and portrait). Such an observation almost echoes the National Geographic article from 1952, which claimed: "Behind all of

\footnotetext{
${ }^{91}$ Qatar 1961, definitives, MiNos. 341-54.

92 Rare stamp examples are, for instance, a 1936-37 stamp from Peru depicting an oil gusher as a motif; also a Canadian stamp from 1950 presenting two oil derricks and an oil gusher.

${ }_{93}$ Ali Behdad and others have analyzed how "locals" were often staged in early photographs. Sometimes, however, "the Orientalist photograph depopulates the Orient of its inhabitants, for their presence robs the image of its quest for visual monumentalism and circumvent the possibility of visual appropriation." Ali Behdad, “The Orientalist Photograph," in Photography's Orientalism: New Essays on Colonial Representation, ed. Ali Behdad and Luke Gartlan (Los Angeles: Getty Research Institute, 2013), 22-24, here 24.
} 
the modernization and breathless expansion is Kuwait's ruler, Sheik Abdullah Salim." ${ }^{94}$ By contrast, the stamps seem to imply that ordinary people were supposedly not part of the image that Kuwait's multiple picturesque "business cards" should convey.

Postage stamps from socialist countries like the German Democratic Republic also celebrated infrastructures visually but-in line with socialist iconographydemonstratively placed "the workers" in front of them. Did the state of Kuwait not consider people crucial to its political and social imaginary, or did they have to be tamed and contained through visual absence from its political iconography to fit the intended state image? Can the absence of people in light of the visual dominance of infrastructure be read as a containment strategy of "unruly forces," as Penny Harvey and Hannah Knox have suggested elsewhere? ${ }^{95}$

When thinking about stamps as political symbols, contemporary politics in fact negotiated the conditions and political representation of Kuwaiti citizenship at the time. The same year the stamps were issued the government passed the first Kuwaiti citizenship law. For this law, a new official definition of what being "Kuwaiti" meant had to be found. With the new nationality law, as Farah Al-Nakib has shown, the state intended to create "a singular Kuwaiti national identity through citizenship subordinated to the nation-state previous loyalties to farij, sect, family or tribe." ${ }^{96}$ However, especially the "nationality law's emphasis on origin" produced a lasting differentiation between the townspeople as "original" Kuwaitis (or ahl al-sūr, the ones living inside the 1920 wall) and of "newcomers," the historically nomadic, later sedentarized Bedouin, despite the fact that they had equal shares in the historical formation of Kuwait, as well as people who had historically migrated from places like India, Iran, and Balochistan to Kuwait, who could also not or did not prove their presence within Kuwait Town prior to $1920 .{ }^{97}$ Within Kuwaiti society, the law eventually stimulated a lasting estrangement between these groups, the hadar (settled urbanites including townspeople, merchants, sailors, pearl divers and so forth) and the Bedouin (or badū in local use; nomadic herdsmen and traders) in particular. Moreover, many non-Kuwaitis (like, for example, long-term residents of Iranian origin) and large numbers of incoming workers from other Arab, South Asian, and Western countries, who also lived in Kuwait City, had their hopes of gaining Kuwaiti citizenship dashed overnight by the nationality law. This strained situation relates, at least symbolically, to the absence of people in the pictures in view of the unsolved dilemma of the political representation of the various groups of people living in Kuwait as citizens.

${ }^{94}$ Case, “Boom Time in Kuwait," 800.

95 They write, "The rhetorical narrative force of the developmental promise is thus amplified by those material engagements that reinforce the desire for infrastructural forms to contain unruly forces (human and non-human)." Harvey and Knox, “The Enchantments of Infrastructure," 534.

96 Al-Nakib, "Revisiting Haḍar and Badū in Kuwait," 11 (italics in the original).

${ }^{97}$ See ibid., 11-14. 
Leading up to the country's independence in 1961, the quickly-expanding state apparatus was heavily fueled by oil revenues and became ever more focused on the persona of Shaykh Abdullah as the nexus of centralizing political power. This marked a shift from a diversified political power structure that included various social groups such as seafaring merchants, captains of pearling ships, and Bedouin traders toward a concentration of power in the House of Sabah, which was the sole receiver and distributer of oil revenues. The process of selecting recently built infrastructure and artistically translating them into pictures on Kuwaiti stamps initially decontextualized and defunctionalized them. Yet, in this new context, the images served to create a new infrastructure of political communication and to establish a new, internationally comprehensible state iconography—an iconography with links to other decolonizing nations and petro-states through the visual depiction of oil culture and the symbol of the oil derrick. The 1959 set of stamps set a precedent as an iridescent showcase of petromodernity in urban visual culture.

\subsection{Political Displays Beyond the Oil Stamps}

The first issue of definitive Kuwaiti stamps not only marked the country's postal independence from Britain but also symbolized the initiation of political decolonialization that lead to Kuwait's independence on June 19, 1961. In this context, the new Kuwaiti stamps served as easily disseminated miniature travel guides that functioned as powerful visual icons of national self-representation to people abroad, entering offices, private homes, drawers and albums in Kuwait and elsewhere as a single miniature or as colorful pictorial collages.

In retrospective, the emerging political iconography of the modern petropolis had first been formulated for the cover of al-Kuwayt al-Yawm in 1954. The 1959 set of stamps consolidated the programmatic collage of infrastructure, modern architectural forms, maritime history, and petro-modernity that was continued and enlarged with the next set of stamps (in Kuwaiti Dinar) and the first set of Kuwaiti Dinar paper money and coins.

Kuwait's second set of definitives adopted four more or less identically stamp designs from the previous issue and was released on April 1, 1961, two months prior to independence. The 1961 set followed the imaginaries and narratives of modernization and progress through infrastructure and the representations of petro-modernity (displayed as oil derrick, oil-loading jetty, and Kuwait Airways plane), and also insofar as this set too was devoid of representations of ordinary people. ${ }^{98}$

\footnotetext{
${ }^{98}$ Kuwait 1961, definitives, MiNos. 145-62.
} 


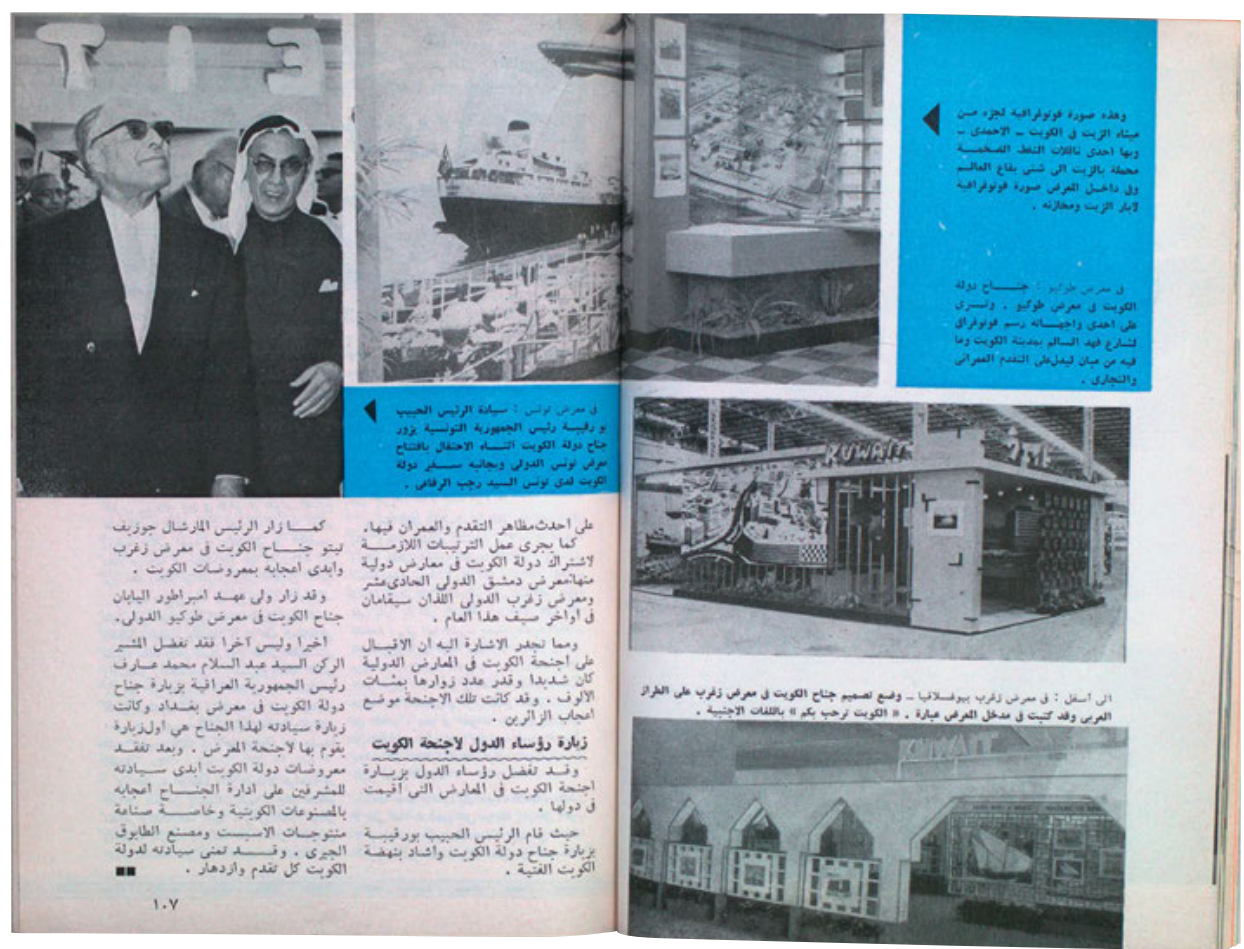

5.25 Spread from al-'Arabī, April 1964, reporting on Kuwaiti pavilions at international exhibitions in Tunis, Tokyo, and Zagreb (clockwise).

Also on April 1, 1961, the Kuwaiti Dinar, as the country's new currency, was put into circulation for the first time. ${ }^{99}$ While displaying a profile portrait of Shaykh Abdullah on the front, the paper money's reverse offered five different designs with motifs of the port of Kuwait in Shuwaikh (quarter dinar); Shuwaikh Secondary School (half dinar); a cement factory (one dinar); a street view of modern-looking middle-income housing (five dinar); and a two-masted dhow (ten dinar). Clearly, the national currency also engaged with the political iconography established by the government gazette and the postage stamps, although it did not refer to petroleum infrastructures as such. Maybe it was too suggestive and thus politically problematic to reference the petroleum industry on the paper version of the oil monies that Shaykh Abdullah received from the Anglo-American oil company.

The influence of this visual program of political representation was lasting and manifested in other forms of political display, too. During the 1960s, the Kuwaiti government frequently showcased the country on an international stage by participating

\footnotetext{
99 To view the first issue of Kuwaiti banknotes, see Central Bank of Kuwait, Banknotes of the First Issue, accessed January 31, 2021, https://www.cbk.gov.kw/en/banknotes-and-coins/banknotes/first-issue.
} 
in various international exhibitions. As one article in al-Arabī magazine reported, Kuwaiti pavilions were shown at exhibitions in Tripoli, Tokyo, Damascus, Zagreb, Tunis, and Milan (fig. 5.25). ${ }^{100}$ Judging from the report and the photographs presented in the article, the Kuwaiti pavilion at Tokyo featured the display of the oil terminal in Ahmadi (infrastructure) and a large-scale photograph of Fahad al-Salem Street (architecture). Oil installations and newly built architecture were also a topic at Tripoli. Photographs of the installations at Tunis and Zagreb document displays of pre-oil maritime culture that, according to the article, were well-received. This indicates that even in the following decade, architecture and large-scale (oil) infrastructures functioned as markers of modernization and petro-modernity with which Kuwait was internationally represented. Yet, its maritime history also played a role in creating the image of Kuwait to audiences abroad, similar to the pictures of traditional boat types included in the 1959 set of stamps and the cover of al-Kuwayt al-Yawm. Moreover, it is noticeable that for Kuwaiti artists such as Abdullah Al Qasser, Tareq Sayid Rajab, and Ibrahim Ismail, the country's maritime past of pearling, fishing, and boat building emerged as important themes in visual arts production during the second half of the twentieth century that equally acknowledged and challenged Kuwait's rapid urban transformation. Then, in August 1990, the country unwillingly experienced a second rupture, a second transformation that, triggered by petroleum, brought the dark side of petroleum to the fore.

\footnotetext{
100 “Al-Kuwayt fĩ l-maārị̣ al-duwaliyya. Bađ̣̣a āyām tashtariku fī márị̣ mīlānū al-ālamī [Kuwait at the International Exhibitions: In a Few Days It Is Participating in Milan's International Exhibition]," al-Arabī, no. 65 (April 1964): 103-7.
} 
